\title{
Characterization and sources of colored dissolved organic matter in a coral reef ecosystem subject to ultramafic erosion pressure (New Caledonia, Southwest Pacific)
}

\author{
Chloé Martias ${ }^{\mathrm{a}, \mathrm{b}, *}$, Marc Tedetti ${ }^{\mathrm{a}}$, François Lantoine ${ }^{\mathrm{c}}$, Léocadie Jamet ${ }^{\mathrm{d}}$, Cécile Dupouy ${ }^{\mathrm{a}, \mathrm{b}}$ \\ ${ }^{a}$ Aix Marseille Univ., Université de Toulon, CNRS, IRD, MIO UM 110, 13288 Marseille, France \\ b Centre IRD de Nouméa, UMR235-MIO, 101 Promenade Roger Laroque BPA5, 98848 Nouméa Cedex, New Caledonia \\ c Sorbonne Universités, UPMC Univ Paris 06, CNRS, Laboratoire d'Ecogeochimie des Environnements Benthiques (LECOB), Observatoire Océanologique, Banyuls sur Mer, France \\ ¿ US191-IMAGO/LAMA, 101 Promenade Roger Laroque BPA5, 98848 Nouméa Cedex, New Caledonia
}

\section{H I G H L I G H T S}

- First report of CDOM and trace metals in the eastern lagoon of New Caledonia

- $\mathrm{S}_{275-295}$ and $\mathrm{SUVA}_{254}$ reveal the importance of CDOM photodegradation in the lagoon.

- CDOM in the lagoon coming from rivers, corals, bacterial activity and open ocean

- Relationships between fluorescent $\mathrm{CDOM}$ and $\mathrm{Ni}, \quad \mathrm{Co}$ and $\mathrm{Mn}$ concentrations

\section{G R A P H I C A L A B S T R A C T}

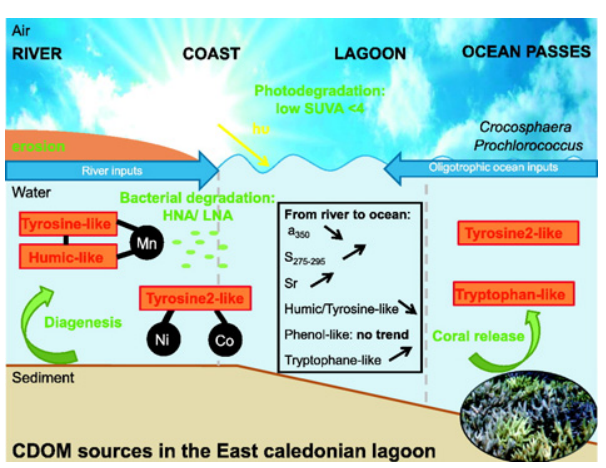

\begin{abstract}
A B S T R A C T
The eastern lagoon of New Caledonia (NC, Southwest Pacific), listed as a UNESCO World Heritage site, hosts the world's second longest double-barrier coral reef. This lagoon receives river inputs, oceanic water arrivals, and erosion pressure from ultramafic rocks, enriched in nickel ( $\mathrm{Ni}$ ) and cobalt ( $\mathrm{Co}$ ). The aim of this study was to characterize colored dissolved organic matter (CDOM), as well as to determine its main sources and its possible relationships (through the use of Pearson correlation coefficients, $r$ ) with biogeochemical parameters, plankton communities and trace metals in the NC eastern lagoon. Water samples were collected in March 2016 along a series of river/lagoon/open-ocean transects. The absorption coefficient at $350 \mathrm{~nm}\left(\mathrm{a}_{350}\right)$ revealed the influence of river inputs on the CDOM distribution. The high values of spectral slope $\left(S_{275-295},>0.03 \mathrm{~m}^{-1}\right)$ and the low values of specific ultraviolet absorbance ( $\mathrm{SUVA}_{254},<4 \mathrm{~L} \mathrm{mg-C}-1 \mathrm{~m}^{-1}$ ) highlighted the photodegradation of CDOM in surface waters. The application of parallel factor analysis (PARAFAC) on excitation-emission matrices (EEMs) allowed the identification of four CDOM components: (1) one humic- and one tyrosine-like fluorophores. They had terrestrial origin, exported through rivers and undergoing photo- and bio-degradation in the lagoon. These two fluorophores were linked to manganese (Mn) in southern rivers $(r=0.46-0.50, n=21, p<0.05)$. (2) A tryptophan-like fluorophore, which exhibited higher levels offshore. It would be potentially released from the coral reef. (3) A second tyrosine-like ("tyrosine 2-like") fluorophore. Linked to Prochlorococcus cyanobacteria $(r=0.39, n=47, p<0.05)$, this fluorophore would have an oceanic origin and enter in the lagoon through its
\end{abstract}

\footnotetext{
* Corresponding author at: Centre IRD de Nouméa, UMR235-MIO, 101 Promenade Roger Laroque BPA5, 98848 Nouméa Cedex, New Caledonia.

E-mail address: chloe.martias@ird.fr (C. Martias).
} 
southern and northern extremities. It also displayed relationships with Ni and Co content $(r=0.53-0.54, n=21$, $p<0.05)$. This work underlines the diversity of CDOM sources in the NC eastern lagoon.

\section{Introduction}

Dissolved organic matter (DOM, $<0.2-0.7 \mu \mathrm{m}$ ), which is the basis of the microbial loop, plays a key biogeochemical role in marine environment (Chisholm, 2000; Carlson and Hansell, 2015; Santinelli, 2016). Chromophoric or colored dissolved organic matter (CDOM) is the component of DOM that absorbs light over a broad range of ultraviolet (UV) and visible wavelengths. The abundance and distribution of CDOM in the ocean is essentially controlled by in situ biological production, terrestrial inputs (sources), photodegradation, microbial consumption (sinks), and deep ocean circulation (Siegel et al., 2002; Nelson et al., 2007; Kowalczuk et al., 2013; Nelson and Siegel, 2013).

$\mathrm{CDOM}$ is the major factor controlling the attenuation of UV radiation in the ocean, protecting marine organisms against harmful solar effects (Mora et al., 2000; Sempéré et al., 2015), but may also compete with chlorophyll $a$ (Chl $a$ ) for the attenuation of photosynthetically available radiation (PAR) (Nelson and Siegel, 2013). CDOM is highly photoreactive and efficiently degraded upon exposure to solar radiation. The photodegradation of CDOM in the surface waters leads to its bleaching (loss of absorption and fluorescence) (Helms et al., 2008; Andrew et al., 2013; Su et al., 2015) and to the production of free radicals, dissolved inorganic carbon, carbon monoxide, carbonyl sulfide, nutrients and low molecular weight organic compounds (Mopper et al., 2015). The photodegradation of CDOM therefore modifies DOM bioavailability to heterotrophic bacteria and significantly impacts the oceanic carbon cycle. Finally, CDOM, particularly humic substances, may interact with trace metals and organic pollutants, modifying their toxicity and fate in the aquatic medium (Gauthier et al., 1986; Mounier et al., 2011).

In coastal marine waters, CDOM may originate from various sources: (1) marine (autochthonous) sources with excretion/release/production at different scales from primary producers (Chen et al., 2017), bacteria (Jørgensen et al., 2011), zooplankton (Steinberg et al., 2004), fishes (Nimptsch et al., 2015), etc. ... (2) terrestrial sources with OM from soil and higher plants carried to marine waters through rivers, runoff or groundwater (Del Vecchio and Blough, 2002; Benner et al., 2005; Lu et al., 2016), and (3) anthropogenic sources with OM released from domestic effluents (Tedetti et al., 2012; Carstea et al., 2016). In coastal (shallow) waters, sediments may also represent a source of CDOM for the water column during sediment resuspension events (Komada et al., 2002; Guigue et al., 2017). Hence, the great variety of CDOM sources and of transformation processes makes the coastal CDOM a complex and heterogeneous pool of organic molecules displaying a broad range of structure and reactivity (Benner et al., 2005; Cao et al., 2016). Whereas most research dealing with the dynamics of CDOM in coastal waters has focused on temperate or high latitude environments, the sources and dynamics of CDOM in tropical coral reef areas remain much less known (Tedetti et al., 2011; Rochelle-Newall et al., 2014; Nelson et al., 2015), although tropical environments have received special attention in recent years due to coral bleaching in the context of global change (Weishaar et al., 2003; Biscéré et al., 2017; Wolanski et al., 2017).

The eastern lagoon of New Caledonia (Southwest Pacific), listed as a UNESCO World Heritage site in 2008, hosts the world's second largest double-barrier coral reef after the Great Barrier Reef. The New Caledonian barrier reef, interspersed with passes, is $1500 \mathrm{~km}$ long and 100$1000 \mathrm{~m}$ width. The eastern lagoon of New Caledonia is impacted by river inputs and the flushing of oligotrophic oceanic water pushed into the lagoon by the external Vauban Current, large cyclonic gyres, tide, and trade winds (Cravatte et al., 2015) through narrow passages
(Andre and Pelletier, 2009). Also, areas near the shore along New Caledonia's east coast have been extensively impacted by the extraction of ultramafic rock for nickel (Ni) and cobalt ( $\mathrm{Co}$ ) exploitation (Cluzel et al., 2001; Fandeur et al., 2009; Dublet et al., 2012, 2015), which accelerates the natural soil erosion. Due to their shoreline location, eroded ultramafic materials are directly transported to the lagoon, as evidenced by remote sensing or in situ measurements. Continuous releasing of trace metals from these ultramafic materials has durably impacted the lagoon ecosystem (Labrosse et al., 2000), including geochemical signatures on the shoreline (Fernandez et al., 2006), sediments and porewater in mangrove swamps (Marchand et al., 2011), benthic populations (Hédouin et al., 2011) and coral reef (Biscéré et al., 2017). No $\mathrm{CDOM}$ or trace metal measurements have however yet been conducted in the eastern lagoon of New Caledonia.

While the quenching effect of trace metals on CDOM has been identified with laboratory experiments (Ryan et al., 1983; Wu et al., 2010; Mounier et al., 2011), few works have highlighted the potential effect of CDOM-metal complexation in natural waters (Stijn et al., 2011). Indeed, the potential complexation between CDOM and trace metals could reduce their toxicity and thus have a positive ecological impact on marine ecosystems (Pandey et al., 2000). In the context of an oligotrophic lagoon undergoing the combined influence of the open ocean and water sheds under erosion pressures, a better understanding of CDOM origins is essential. Therefore, the objective of this study was to characterize and determine the main sources of CDOM in the eastern lagoon of New Caledonia, subjected to ultramafic erosion pressure, along a series of river/lagoon/open-ocean transects. The sampling period was the wet season in order to capture potential river plumes or biological bloom events in the lagoon. Along with CDOM, biogeochemical parameters, plankton communities and trace metals were determined to better differentiate terrestrial and marine sources of CDOM and its possible relationships with trace metals. To our knowledge, this work is the first investigation of the coupling between CDOM properties, trace metal concentrations and phyto- and bacterio-plankton communities in a coral reef ecosystem submitted to erosion pressure from mining activities.

\section{Materials and methods}

\subsection{Study area}

New Caledonia's main island (Grande Terre, $16,360 \mathrm{~km}^{2}$ ) is surrounded by a $1500 \mathrm{~km}$ long and 100-1000 m width barrier reef (Fig. 1). Reef and lagoon together cover an area of approximately $22,200 \mathrm{~km}^{2}, 86 \%$ of which is lagoon. In the eastern lagoon, water depth varies from 40 to $80 \mathrm{~m}$, with a submarine valley (Jollit et al., 2010), and water temperature is generally $>25^{\circ} \mathrm{C}$. The barrier reef is almost totally submerged except at some locations. A specific feature of the eastern coast is the numerous rivers flowing into bays (Fig. 1). From South to North, these are the Yaté, Pourina, Koualoue-Ouinné, Thio, Canala, Houailou, Ponerihouen and Tchamba, Tiwaka and Ouaième. These rivers drain watersheds of different geological origins. The southern rivers drain ultramafic lands, while the northern rivers drain karstic lands (Bonvallot et al., 2013). The origin of surface water in the eastern lagoon is a mixture of water from rivers, depending on the rain intensity, and oceanic water arrivals through passes from the warm tropical area surrounding the Vanuatu island group (Marchesiello et al., 2010). New Caledonia's lagoon was affected by coral bleaching in February 2016 (Payri et al., 2017), and undergoes 


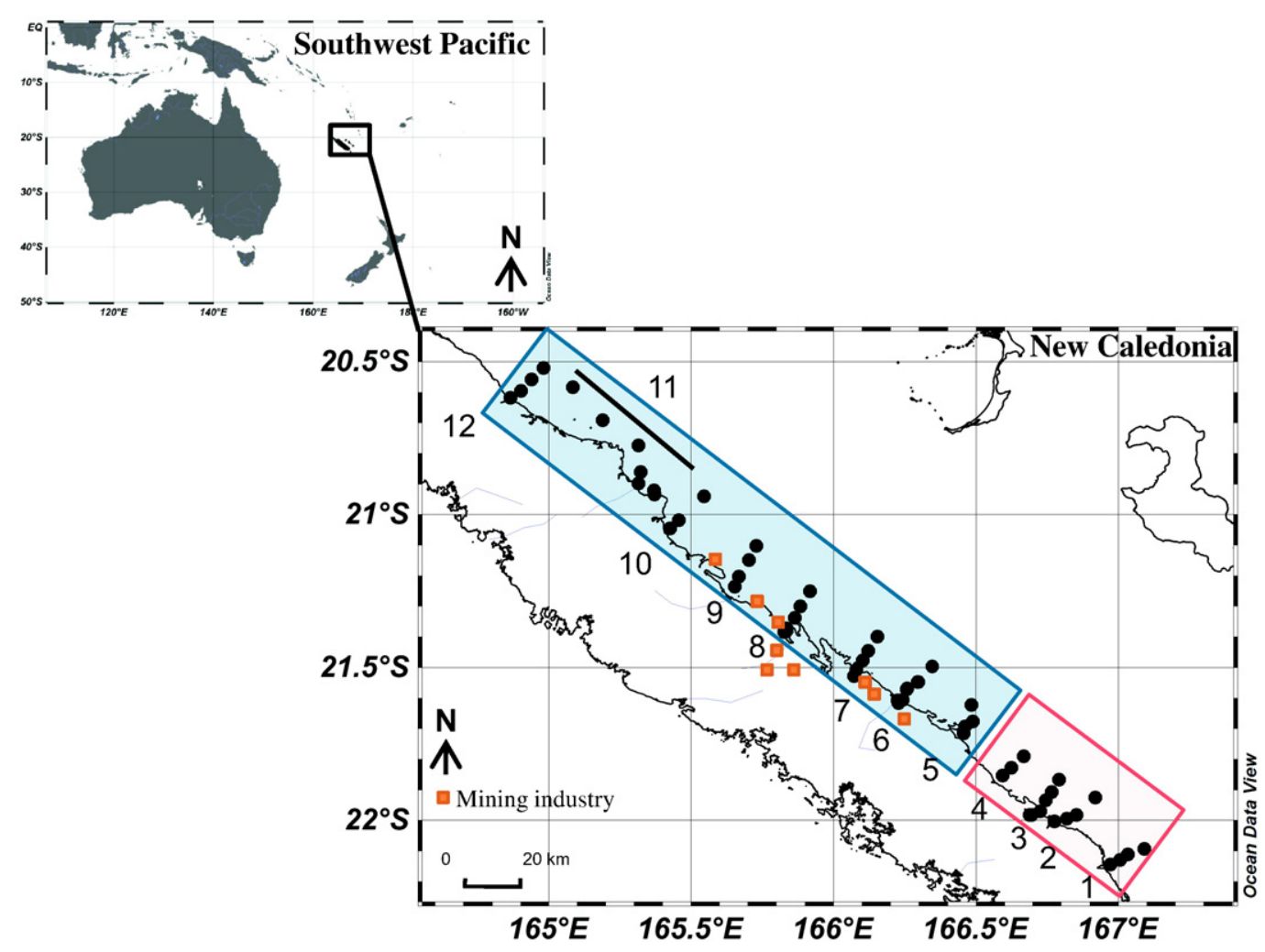

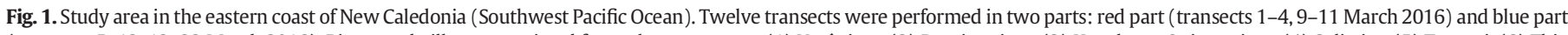

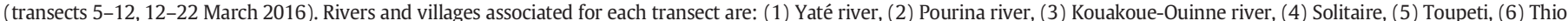

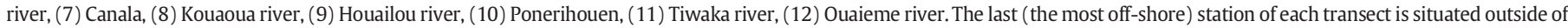
the barrier reef (see Table 1). Ocean Data View software version 4.6.5, Schlitzer, R., http://odv.awi.de, 2014.

pressures from local human activities, principally fishing and Ni extraction, which have been impacting the lagoon ecosystem for a long time.

\subsection{Sampling}

Samples were collected on board R/V Alis during the CALIOPE 3 cruise (9-22 March 2016, austral summer) along $278 \mathrm{~km}$ of the east coast through 12 transects including river, coastal, lagoon and offshore (oceanic) waters (Fig. 1; Table 1). This cruise was the third cruise of the CALIOPE IRD research project (CALIOPE 1 and CALIOPE 2 cruises conducted in October 2011 and March 2014, respectively) (Dupouy et al., 2014). A total of 57 stations were sampled: transect 1-4 from South to North (9-11 March), and transect 5-12 from North to South (12-22 March). All transects were carried out from the bay to ocean, except transect 11 from Hienghene to Poindimié (Fig. 1; Table 1). A dinghy was deployed for sampling in shallow waters ( $<10$-m depth), i.e., in all river stations (ST1, ST2, ST8, ST9, ST12-ST14, ST16, ST18, ST19), 9 coastal stations (S1, S7, S39, S33, S28, S27, S21, S23, S12) and 2 lagoon stations (S34, S16), when the weather was favorable (Table 1).

Strong rains were observed on 10 March (accumulated rainfall of $622 \mathrm{~mm}$ in March 2016 compared to a yearly average of $135 \mathrm{~mm}$ ). At the North of Ouaième (transect 12) and Canala (transect 7), 24-h accumulated rainfall was 107 and $153 \mathrm{~mm}$, respectively. This rainy weather persisted until 12-13 March with a strong rain convergence cell above Borindi (transect 5), leading to an accumulated rainfall of $207 \mathrm{~mm}$ (National Meteorology of New Caledonia). Tide levels during sampling varied between 0.47 and $1.14 \mathrm{~m}$.

Salinity, temperature and fluorescence of total Chl $a$ were measured in the water column using a conductivity temperature depth (CTD)/rosette system including a SeaBird Electronics (SBE) 911 plus, a Wetlabs C-meter and 8-L Niskin bottles. For coastal, lagoon and oceanic stations, samples were collected at $2-\mathrm{m}$ depth with all 8 Niskin bottles of $8-\mathrm{L}$ capacity for CDOM, nutrient, Chl $a$, organic carbon and plankton community analyses. For river, samples were collected at 1-m depth aboard the Alis' dinghy with a GOFLO bottle for CDOM, organic carbon and trace metal analyses. Coastal stations at the same transect as river stations sampled for trace metal analyses were also sampled for trace metals with a GOFLO bottle. Coastal stations at transect 2, 4 and 5 were not sampled for trace metals with a GOFLO bottle because no river stations were sampled at these transects. The GOFLO bottle was cleaned with hydrochloric acid $(\mathrm{HCl}) 1 \mathrm{~N}$ and 3 times with Milli-Q water between each transect.

Water samples for CDOM were immediately filtered onboard in a low vacuum on $0.2 \mu \mathrm{m}$ Millipore GSWP filters in acid-cleaned Nalgene filtering units. Between each sampling operation, the whole filtration system was cleaned by filtering Milli-Q water. Filtered samples were stored in pre-combusted $\left(450^{\circ} \mathrm{C}, 6 \mathrm{~h}\right) 25-\mathrm{mL}$ Schott glass bottles, and kept in the dark at $4{ }^{\circ} \mathrm{C}$. Unfiltered samples for total organic carbon (TOC) were stored in pre-combusted glass ampoules, flame-sealed after addition of $10 \mathrm{~mL}$ of $85 \%$ phosphoric acid, and kept in the dark at $4{ }^{\circ} \mathrm{C}$. Forty milliliters of unfiltered water was immediately mixed with $20 \mu \mathrm{L}$ of mercury chloride and kept in the dark at $4{ }^{\circ} \mathrm{C}$ for nutrient analyses. For particulate organic carbon (POC), $2 \mathrm{~L}$ of water were filtered on pre-combusted $25-\mathrm{mm} \mathrm{GF} / \mathrm{F}$ filters, further kept at $-20^{\circ} \mathrm{C}$. For Chl $a$, $2.5 \mathrm{~L}$ of water were filtered on 47-mm GF/F filters, immediately kept at $-20^{\circ} \mathrm{C}$ and later at $-80^{\circ} \mathrm{C}$. Samples for flow cytometry were prepared from $1.8 \mathrm{~mL}$ of water fixed with $200 \mu \mathrm{L}$ of paraformaldehyde ( $4 \%$ final concentration). After a reaction time of $15 \mathrm{~min}$ in ambient temperature, samples were frozen and first stored at $-169{ }^{\circ} \mathrm{C}$ in liquid $\mathrm{N}_{2}$ and later at $-80^{\circ} \mathrm{C}$ until analysis.

\subsection{CDOM absorption}

CDOM absorbance $\left(A_{\lambda}\right)$ was measured on $0.2-\mu$ m filtered samples stirred at low pressure $(30 \mathrm{rpm})$ at room temperature. Measurements 
Table 1

Characteristics of stations sampled at 2-m depth in the eastern coast of New Caledonia during CALIOPE 3 cruise (9-22 March 2016).

\begin{tabular}{|c|c|c|c|c|c|c|c|c|c|c|}
\hline Transect & Station & $\begin{array}{l}\text { Day } \\
\text { TU }\end{array}$ & $\begin{array}{l}\text { Hour } \\
\text { TU }\end{array}$ & $\begin{array}{l}\text { Longitude } \\
\text { [East] }\end{array}$ & $\begin{array}{l}\text { Latitude } \\
\text { [ }{ }^{\circ} \text { South] }\end{array}$ & $\begin{array}{l}\text { Depth } \\
(\mathrm{m})\end{array}$ & Transect name & $\begin{array}{l}\text { Water } \\
\text { type }\end{array}$ & Tide & Analyses \\
\hline 1 & S1 & 9 & 4 & 166.972 & -22.144 & 53.1 & Yaté & Coast & Increasing & $\mathrm{CDOM} /$ nutrients/Chl $a / \mathrm{TOC} /$ plankton communities/trace metals \\
\hline 1 & S51 & 19 & 20 & 167.033 & -22.111 & 76 & Yaté & Ocean & Increasing & $\mathrm{CDOM} /$ nutrients/Chl $a / \mathrm{TOC} /$ plankton communities \\
\hline 1 & S52 & 19 & 21 & 167.091 & -22.093 & 313 & Yate & Ocean & Increasing & $\mathrm{CDOM} /$ nutrients/Chl $a / \mathrm{TOC} /$ plankton communities \\
\hline 1 & S53 & 20 & 0 & 167.005 & -22.129 & 54 & Yaté & Lagoon & Decreasing & $\mathrm{CDOM} /$ nutrients/Chl $a / \mathrm{TOC} /$ plankton communities \\
\hline 2 & $\mathrm{~S} 2$ & 9 & 19 & 166.775 & -22.003 & 56 & Pourina & Coast & Increasing & $\mathrm{CDOM} /$ nutrients/Chl $a / \mathrm{TOC} /$ plankton communities \\
\hline 2 & S3 & 9 & 21 & 166.818 & -21.993 & 55 & Pourina & Lagoon & Decreasing & $\mathrm{CDOM} /$ nutrients/Chl $a / \mathrm{TOC} /$ plankton communities \\
\hline 2 & S47 & 19 & 0 & 166.919 & -21.924 & 315 & Pourina & Ocean & Low & $\mathrm{CDOM} /$ nutrients/Chl $a / \mathrm{TOC} /$ plankton communities \\
\hline 2 & S4 & 9 & 23 & 166.853 & -21.981 & 40 & Pourina & Ocean & Decreasing & $\mathrm{CDOM} /$ nutrients/Chl $a / \mathrm{TOC} /$ plankton communities \\
\hline 3 & S5 & 10 & 2 & 166.766 & -21.906 & 45 & Kouakoue & Ocean & Low & $\mathrm{CDOM} /$ nutrients/Chl $a / \mathrm{TOC} /$ plankton communities \\
\hline 3 & S6 & 10 & 3 & 166.791 & -21.866 & 150 & Kouakoue & Ocean & Increasing & $\mathrm{CDOM} /$ nutrients/Chl $a / \mathrm{TOC} /$ plankton communities \\
\hline 3 & S7 & 10 & 20 & 166.726 & -21.969 & 50 & Kouakoue & Coast & Increasing & $\mathrm{CDOM} /$ nutrients/Chl $a / \mathrm{TOC} /$ plankton communities/trace metals \\
\hline 3 & S8 & 10 & 21 & 166.745 & -21.934 & 75 & Kouakoue & Lagoon & High & $\mathrm{CDOM} /$ nutrients/Chl $a / \mathrm{TOC} /$ plankton communities \\
\hline 3 & ST1 & 10 & 20 & 166.688 & -21.982 & 2 & Kouakoue & River & Increasing & $\mathrm{CDOM} / \mathrm{TOC} /$ trace metals \\
\hline 3 & ST2 & 10 & 20 & 166.694 & -21.981 & 2 & Kouakoue & River & Increasing & $\mathrm{CDOM} / \mathrm{TOC} /$ trace metals \\
\hline 4 & S9 & 11 & 0 & 166.593 & -21.853 & 50 & Solitaire & Coast & Decreasing & $\mathrm{CDOM} /$ nutrients/Chl $a / \mathrm{TOC} /$ plankton communities \\
\hline 4 & S10 & 11 & 1 & 166.624 & -21.827 & 50 & Solitaire & Lagoon & Decreasing & $\mathrm{CDOM} /$ nutrients/Chl $a / \mathrm{TOC} /$ plankton communities \\
\hline 4 & S11 & 11 & 3 & 166.668 & -21.789 & 260 & Solitaire & Ocean & Low & $\mathrm{CDOM} /$ nutrients/Chl $a / \mathrm{TOC} /$ plankton communities \\
\hline 5 & S40 & 17 & 22 & 166.484 & -21.621 & 571 & Toupeti & Ocean & Low & $\mathrm{CDOM} /$ nutrients/Chl $a / \mathrm{TOC} /$ plankton communities \\
\hline 5 & S41 & 18 & 0 & 166.489 & -21.675 & 40 & Toupeti & Ocean & Increasing & $\mathrm{CDOM} /$ nutrients/Chl $a / \mathrm{TOC} /$ plankton communities \\
\hline 5 & S42 & 18 & 1 & 166.461 & -21.692 & 45 & Toupeti & Lagoon & Increasing & $\mathrm{CDOM} /$ nutrients/Chl $a / \mathrm{TOC} /$ plankton communities \\
\hline 5 & S43 & 18 & 2 & 166.456 & -21.714 & 45 & Toupeti & Coast & Increasing & $\mathrm{CDOM} /$ nutrients/Chl $a / \mathrm{TOC} /$ plankton communities \\
\hline 6 & S36 & 17 & 0 & 166.295 & -21.547 & 43 & Thio & Ocean & Increasing & $\mathrm{CDOM} /$ nutrients/Chl $a / \mathrm{TOC} /$ plankton communities \\
\hline 6 & S38 & 17 & 5 & 166.258 & -21.568 & 37 & Thio & Lagoon & Decreasing & $\mathrm{CDOM} /$ nutrients/Chl $a / \mathrm{TOC} /$ plankton communities \\
\hline 6 & S37 & 17 & 2 & 166.345 & -21.495 & 673 & Thio & Ocean & Increasing & $\mathrm{CDOM} /$ nutrients/Chl $a / \mathrm{TOC} /$ plankton communities \\
\hline 6 & S39 & 17 & 19 & 166.242 & -21.605 & 12 & Thio & Coast & Decreasing & $\mathrm{CDOM} /$ nutrients/Chl $a / \mathrm{TOC} /$ plankton communities/trace metals \\
\hline 6 & ST16 & 17 & 19 & 166.224 & -21.607 & 2 & Thio & River & Decreasing & $\mathrm{CDOM} / \mathrm{TOC} /$ trace metals \\
\hline 6 & ST18 & 17 & 19 & 166.257 & -21.570 & 2 & Thio & River & Decreasing & $\mathrm{CDOM} / \mathrm{TOC} /$ trace metals \\
\hline 6 & ST19 & 17 & 19 & 166.227 & -21.616 & 2 & Thio & River & Decreasing & $\mathrm{CDOM} / \mathrm{TOC} /$ trace metals \\
\hline 7 & S32 & 16 & 4 & 166.154 & -21.398 & 400 & Canala & Ocean & Decreasing & $\mathrm{CDOM} /$ nutrients/Chl $a / \mathrm{TOC} /$ plankton communities \\
\hline 7 & S33 & 16 & 19 & 166.080 & -21.507 & 35 & Canala & Coast & Decreasing & $\mathrm{CDOM} /$ nutrients/Chl $a / \mathrm{TOC} /$ plankton communities/trace metals \\
\hline 7 & S35 & 16 & 21 & 166.122 & -21.444 & 40 & Canala & Ocean & Low & $\mathrm{CDOM} /$ nutrients/Chl $a / \mathrm{TOC} /$ plankton communities \\
\hline 7 & S34 & 16 & 20 & 166.102 & -21.476 & 50 & Canala & Lagoon & Decreasing & $\mathrm{CDOM} /$ nutrients/Chl $a / \mathrm{TOC} /$ plankton communities/trace metals \\
\hline 7 & ST14 & 16 & 19 & 166.071 & -21.527 & 2 & Canala & River & Decreasing & $\mathrm{CDOM} / \mathrm{TOC} /$ trace metals \\
\hline 8 & S29 & 15 & 19 & 165.864 & -21.336 & 50 & Kouaoua & Lagoon & Decreasing & $\mathrm{CDOM} /$ nutrients/Chl $a / \mathrm{TOC} /$ plankton communities \\
\hline 8 & S31 & 16 & 0 & 165.917 & -21.250 & 301 & Kouaoua & Ocean & Increasing & $\mathrm{CDOM} /$ nutrients/Chl $a / \mathrm{TOC} /$ plankton communities \\
\hline 8 & S28 & 15 & 4 & 165.835 & -21.378 & 15 & Kouaoua & Coast & Decreasing & $\mathrm{CDOM} /$ nutrients/Chl $a / \mathrm{TOC} /$ plankton communities/trace metals \\
\hline 8 & S30 & 15 & 22 & 165.883 & -21.299 & 50 & Kouaoua & Ocean & Increasing & $\mathrm{CDOM} /$ nutrients/Chl $a / \mathrm{TOC} /$ plankton communities \\
\hline 8 & ST12 & 15 & 4 & 165.826 & -21.383 & 2 & Kouaoua & River & Decreasing & $\mathrm{CDOM} / \mathrm{TOC} /$ trace metals \\
\hline 8 & ST13 & 15 & 4 & 165.834 & -21.371 & 2 & Kouaoua & River & Decreasing & $\mathrm{CDOM} / \mathrm{TOC} /$ trace metals \\
\hline 9 & S24 & 14 & 20 & 165.729 & -21.101 & 500 & Houailou & Ocean & Increasing & $\mathrm{CDOM} /$ nutrients/Chl $a / \mathrm{TOC} /$ plankton communities \\
\hline 9 & S26 & 14 & 23 & 165.667 & -21.202 & 30 & Houailou & Lagoon & Increasing & $\mathrm{CDOM} /$ nutrients/Chl a/TOC/plankton communities \\
\hline 9 & S27 & 15 & 1 & 165.652 & -21.235 & 30 & Houailou & Coast & Increasing & $\mathrm{CDOM} /$ nutrients/Chl $a / \mathrm{TOC} /$ plankton communities/trace metals \\
\hline 9 & S25 & 14 & 22 & 165.703 & -21.148 & 50 & Houailou & Ocean & Increasing & $\mathrm{CDOM} /$ nutrients/Chl $a / \mathrm{TOC} /$ plankton communities \\
\hline 10 & S20 & 13 & 4 & 165.457 & -21.018 & 48 & Ponerihouen & Lagoon & Decreasing & $\mathrm{CDOM} /$ nutrients/Chl $a / \mathrm{TOC} /$ plankton communities \\
\hline 10 & S19 & 13 & 2 & 165.544 & -20.940 & 104 & Ponerihouen & Ocean & Decreasing & $\mathrm{CDOM} /$ nutrients/Chl $a / \mathrm{TOC} /$ plankton communities \\
\hline 10 & S21 & 13 & 19 & 165.425 & -21.044 & 21 & Ponerihouen & Coast & Increasing & $\mathrm{CDOM} /$ nutrients/Chl $a / \mathrm{TOC} /$ plankton communities/trace metals \\
\hline 11 & S16 & 12 & 4 & 165.085 & -20.583 & 1000 & Hienghene (Tiwaka) & Lagoon & Low & $\mathrm{CDOM} /$ nutrients/Chl $a / \mathrm{TOC} /$ plankton communities/trace metals \\
\hline 11 & S17 & 12 & 20 & 165.189 & -20.690 & 41 & Hienghene (Tiwaka) & Lagoon & Increasing & $\mathrm{CDOM} /$ nutrients/Chl $a / \mathrm{TOC} /$ plankton communities \\
\hline 11 & S22 & 13 & 22 & 165.322 & -20.860 & 50 & Touho-Poindimie & Lagoon & Increasing & $\mathrm{CDOM} /$ nutrients/Chl $a / \mathrm{TOC} /$ plankton communities \\
\hline 11 & S23 & 14 & 0 & 165.315 & -20.898 & 24 & Poindimié & Coast & High & $\mathrm{CDOM} /$ nutrients/Chl $a / \mathrm{TOC} /$ plankton communities/trace metals \\
\hline 11 & S18 & 12 & 22 & 165.315 & -20.773 & 550 & Hienghene (Tiwaka) & Ocean & Increasing & $\mathrm{CDOM} /$ nutrients/Chl $a / \mathrm{TOC} /$ plankton communities \\
\hline 11 & ST8 & 14 & 0 & 165.371 & -20.934 & 2 & Hienghene & River & High & $\mathrm{CDOM} / \mathrm{TOC} /$ trace metals \\
\hline 11 & ST9 & 14 & 0 & 165.369 & -20.920 & 2 & Hienghene & River & High & $\mathrm{CDOM} / \mathrm{TOC} /$ trace metals \\
\hline 12 & S15 & 12 & 2 & 164.981 & -20.519 & 460 & Ouaieme & Ocean & Decreasing & $\mathrm{CDOM} /$ nutrients/Chl $a / \mathrm{TOC} /$ plankton communities \\
\hline 12 & $\mathrm{~S} 12$ & 11 & 20 & 164.865 & -20.617 & 9 & Ouaieme & Coast & Increasing & $\mathrm{CDOM} /$ nutrients/Chl $a / \mathrm{TOC} /$ plankton communities/trace metals \\
\hline 12 & $\mathrm{~S} 13$ & 11 & 21 & 164.903 & -20.594 & 400 & Ouaieme & Lagoon & High & $\mathrm{CDOM} /$ nutrients/Chl $a / \mathrm{TOC} /$ plankton communities \\
\hline 12 & S14 & 11 & 23 & 164.939 & -20.557 & 600 & Ouaieme & Ocean & Decreasing & $\mathrm{CDOM} /$ nutrients/Chl $a / \mathrm{TOC} /$ plankton communities \\
\hline
\end{tabular}

were conducted from 275 to $800 \mathrm{~nm}$ in $2 \mathrm{~nm}$ intervals using a liquid core waveguide system with an optical pathlength of $2 \mathrm{~m}$ (LLCW, World Precision Instruments, Inc.) and a Hamamatsu spectrophotometer C10082CA. Between each processing of the sample, the capillary waveguide cell was flushed and filled with purified water used as blank according to the method described by Kowalczuk et al. (2013). After the acquisition of a dark (detector out) and the reference blank with Milli-Q water, each spectrum was measured in triplicate to ensure replicability. All measured spectra were corrected for residual absorbance, by assuming that the average of measured values over a $5 \mathrm{~nm}$ interval around $698 \mathrm{~nm}$ must be 0 , and shifting the spectra as proposed by Organelli et al. (2014). A spectrum of a $100 \mathrm{~g} \mathrm{~L}^{-1} \mathrm{NaCl}$ solution made with combusted $99.99 \%$ pure $\mathrm{NaCl}$ salt was run to correct the effect of salinity on pure water absorption. The relative instrument sensitivity, given by the manufacturer, is between 10 and $28 \%$ with a spectral resolution of $2 \mathrm{~nm}$. $A_{\lambda}$ is measured at $\pm 10^{-6}$. $A_{\lambda}$ values were then converted into CDOM absorption coefficients, $a_{\lambda}\left(\mathrm{m}^{-1}\right)$, using the following equation:

$\alpha_{\lambda}=\frac{2.303 A_{\lambda}}{L}$

where $A_{\lambda}$ is the absorbance at wavelength $\lambda$ (dimensionless) and $\mathrm{L}$ is the pathlength (m). The absorption of CDOM at $350 \mathrm{~nm}$ was used as a proxy for CDOM concentrations (Biers et al., 2007; Kowalczuk et al., 2010). The detection limit of $a_{350}$ was estimated at $0.05 \mathrm{~m}^{-1}$. 
Spectral indicators were determined from absorption coefficients to have more information about CDOM structure (molecular weight, aromaticity): (1) Spectral slope, $\mathrm{S}\left(\mathrm{nm}^{-1}\right)$, was computed according to the equation:

$a \lambda=a \lambda 0 \times e^{-S(\lambda-\lambda 0)}$

where $a_{\lambda}$ is the absorption coefficient at the wavelength $\lambda, a_{\lambda 0}$ is the absorption coefficient at reference wavelength $\lambda_{0}$ and $S$ is the spectral slope from $\lambda_{0}$ to $\lambda\left(\lambda_{0}<\lambda\right)$. Two spectral ranges were used for the $S$ calculation: $275-295 \mathrm{~nm}\left(\mathrm{~S}_{275-295}\right)$ and $350-400 \mathrm{~nm}\left(\mathrm{~S}_{350-400}\right)$. The slope ratio (SR) was calculated as the ratio of $S_{275-295}$ to $S_{350-400}$ according to Helms et al. (2008). $S_{350-400}$ was determined by applying a non-linear (exponential) least-squares fit, whereas $\mathrm{S}_{275-295}$ was obtained by applying a linear least-squares fit to the log-transformed data. SR is related to the molecular weight distribution of $\mathrm{CDOM}$ with low values $(<1)$ indicative of enrichment in high molecular weight (HMW) compounds and high values $(>1)$ indicative of enrichment in low molecular weight (LMW) compounds (Helms et al., 2008). (2) We also determined the

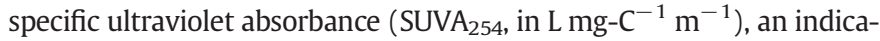
tor of aromaticity of $\mathrm{CDOM}$, by dividing the absorption coefficient at $254 \mathrm{~nm}$ by the DOC concentration ( $\mathrm{mg} \mathrm{L}^{-1}$ ) according to Weishaar et al. (2003) and Helms et al. (2008).

\subsection{CDOM fluorescence}

Fluorescence excitation-emission matrices (EEMs) were conducted using a Hitachi F-7000 spectrofluorometer in accordance with Tedetti et al. (2012) and Ferretto et al. (2017). Samples were allowed to reach room temperature in the dark and then transferred into a $1 \mathrm{~cm}$ pathlength for UV silica quartz cuvette $(170-2600 \mathrm{~nm})$, thermostated at $20^{\circ} \mathrm{C}$ in the cell holder by an external circulating water bath. EEMs were generated over excitation wavelengths $\left(\lambda_{\mathrm{Ex}}\right)$ between 220 and $550 \mathrm{~nm}$ in $5 \mathrm{~nm}$ intervals, and emission wavelengths $\left(\lambda_{\mathrm{Em}}\right)$ between 280 and $550 \mathrm{~nm}$ in $2 \mathrm{~nm}$ intervals, with $5 \mathrm{~nm}$ bandwidths on both Ex and Em sides. The scan speed was $1200 \mathrm{~nm} \mathrm{~min}{ }^{-1}$, the time response $0.5 \mathrm{~s}$, and the PMT voltage $700 \mathrm{~V}$ (Tedetti et al., 2011; Mendoza et al., 2012). Spectral corrections for Ex and Em were made in accordance with the manufacturer (Hitachi F-7000 Instruction Manual), as described in Tedetti et al. (2012). Blanks (pure water) and solutions of quinine sulfate dihydrate (Fluka, purum for fluorescence) in $0.05 \mathrm{M}$ sulphuric acid $\left(\mathrm{H}_{2} \mathrm{SO}_{4}\right)$ were run with each set of samples.

With regard to the low absorption coefficients recorded here, samples were not corrected for inner filtering effects (Helms et al., 2008; Murphy et al., 2013; Tedetti et al., 2016). EEMs were (1) normalized to the water Raman scattering peak to account for the daily variations in the instrument sensitivity, (2) blank-corrected by subtracting the pure water EEM (i.e., the average of the pure water EEMs generated before, during and after the analyses of a set of samples), and (3) converted into quinine sulfate units (QSU), where 1 QSU corresponds to the fluorescence of $1 \mu \mathrm{g} \mathrm{L}^{-1}$ quinine sulfate in $0.05 \mathrm{M} \mathrm{H}_{2} \mathrm{SO}_{4}$ at $\lambda_{\mathrm{Ex}} / \lambda_{\mathrm{Em}}$ of $350 / 450 \mathrm{~nm}$. The slope of the linear regression of quinine sulfate standards was 11.2 with a correlation coefficient $(r)>0.99$. The detection limit of the fluorescence measurement was 0.10 QSU.

Parallel factor analysis (PARAFAC) is a statistical decomposition technique used to extract the most representative fluorescent components within an EEM dataset. PARAFAC was run with MATLAB R2010A using the DOMFLUOR toolbox. Our EEM dataset was composed of 151 samples from CALIOPE 3 but also CALIOPE 1 and 2 cruises, i.e., surface marine samples ( $47 \times 3$ : CALIOPE $1-3$ ) and 10 river samples (CALIOPE 3 only). The model was validated using random split half analysis and the number of components was determined by the examination of residuals from models, the explained variance values and Tucker congruence coefficient (TCC) values, as in Gao and Guéguen (2016). For each component is given fluorescent intensity at the maximum (Fmax), which is the product of the maximal excitation and the maximal emission loadings by the score (Murphy et al., 2013).

\subsection{Biogeochemical and biological analyses}

NOx, the sum of nitrate $\left(\mathrm{NO}_{3}^{-}\right)$and nitrite $\left(\mathrm{NO}_{2}^{-}\right)$, and silicate $\left(\mathrm{Si}(\mathrm{OH})_{4}\right)$ were analyzed by colorimetry on an auto-analyzer with continuous flux (AA3 Bran + Luebbe autoanalyser) (Murphy and Riley, 1962; Raimbault et al., 1990). The coefficient of variation (CV) between replicates was $<0.3 \%$. After grinding on the GF/F filter, Chl $a$ extracted in $90 \%$ acetone was analyzed with a fluorometer Trilogy Turner 7200-000. TOC concentration was determined on 3 replicates using a TOC-V analyzer (Shimadzu) according to the method by Luciani et al. (2008). POC was analyzed by a persulfate wet-oxidation method under slightly alkaline conditions (Raimbault et al., 1999). Dissolved organic carbon (DOC) concentrations were estimated as the difference between TOC and POC concentrations. It should be noted that POC data are not presented in this paper. Pico- and nano-phytoplankton, as well as heterotrophic bacteria abundances were analyzed by flow cytometry using a FACSCantoII BD Science (Plateforme Cytométrie-Imagerie Laboratoire Arago, Banyuls sur Mer). Phytoplankton communities were classified according to their optical properties as Prochlorococcus (Proc), Crocosphaera (Croc), Synechococcus (Syn), nanoeukaryotes (NanoEuk) and picoeukaryotes (PicoEuk). Syn were further separated into two subgroups in accordance with their phycoerythrin fluorescence intensity: SynFL2- and SynFL2. Total bacteria were separated in two groups according to Lebaron et al. (2001): HNA bacteria (high nucleic acid content), responsible for the major share of the bulk activity, and LNA bacteria (low nucleic acid content).

\subsection{Trace metal analyses}

Trace metal concentrations were determined in accordance with Moreton (2009) in 3 steps: (1) Simultaneous treatment of 3 preconcentration cartridges under a laminar flow hood on board, (2) elution of cartridges at the AEL (Analytical Environmental Laboratory in Nouméa), (3) determination of dissolved concentrations of some trace metals, i.e., Co, copper ( $\mathrm{Cu}$ ), manganese $(\mathrm{Mn})$ and $\mathrm{Ni}$ using a Perkin Elmer Nexion $350 \times$ Inductively Coupled Plasma Mass Spectrometer (ICP-MS) with a six-point calibration, ranging from 0.5 to $100 \mu \mathrm{g} \mathrm{L}^{-1}$. Standards were prepared by diluting a $100 \mathrm{mg} \mathrm{L}^{-1}$ multi-element solution (ICP-MS grade-CPA). A reference sample (TMDA 51.4) (values: Co $=70.6 \pm 4.5 \mu \mathrm{g} \mathrm{L}^{-1}, \mathrm{Cu}=80.7 \pm 6.9 \mu \mathrm{g} \mathrm{L}^{-1}, \mathrm{Mn}=84.3 \pm 6.6$ $\mu \mathrm{g} \mathrm{L}{ }^{-1}, \mathrm{Ni}=65.7 \pm 4.5 \mu \mathrm{g} \mathrm{L}^{-1}$ ) was run to certify the series of metal data acquisitions. Milli-Q was used as blank. ${ }^{63} \mathrm{Cu},{ }^{55} \mathrm{Mn}$ and ${ }^{60} \mathrm{Ni}$ were analyzed by kinetic energy discrimination (KED) with helium as the collision gas, while ${ }^{59} \mathrm{Co}$ was analyzed in standard mode. Detection limits were 7, 9, 8 and $3 \mathrm{ng} \mathrm{L}^{-1}$ for $\mathrm{Co}, \mathrm{Cu}, \mathrm{Mn}$ and $\mathrm{Ni}$, respectively.

\subsection{Statistics}

Two Principal Component Analysis (PCAs) were conducted on the basis of Pearson's correlation matrices using XLSTAT 2011.2.05. PCA (a) was applied on 47 samples, including coastal, lagoon and oceanic stations, for various variables: salinity, biogeochemical parameters $\left(\mathrm{NO}_{\mathrm{X}}, \mathrm{Si}(\mathrm{OH})_{4}, \mathrm{TOC}, \mathrm{Chl} a\right.$ concentrations), plankton communities (Proc, Croc, SynFL2-, SynFL2, NanoEuk, PicoEuk, HNA and LNA bacteria), CDOM absorption parameters $\left(\mathrm{a}_{350}, \mathrm{~S}_{275-295}\right.$, SR, SUVA 254 ) and CDOM fluorescence parameters (fluorescence intensities of the four components). PCA (b) was applied only to all (10) river samples, 9 coastal stations and 2 lagoon stations (21 samples) for trace metal concentrations ( $\mathrm{Co}, \mathrm{Cu}, \mathrm{Mn}, \mathrm{Ni}$ ), and fluorescence intensities of the four CDOM components. Ocean Data View (ODV) software version 4.6.5 (Schlitzer, R., http://odv.awi.de, 2014) was employed for the spatial representation of CDOM and biogeochemical parameters. The spatial interpolation/ gridding of data was performed using Data-Interpolating Variational 
Analysis (DIVA) (Barth et al., 2010; Troupin et al., 2012). ArcGIS software was used for the spatial distribution of trace metals.

\section{Results}

3.1. Spatial distribution of salinity, biogeochemical and biological parameters

Salinity, $\mathrm{Si}(\mathrm{OH})_{4}, \mathrm{NO}_{\mathrm{X}}$, Chl $a$ and TOC concentrations are shown in Table SI-1 and their spatial distribution in Fig. 2. Salinity ranged from 31.1 to 35.5 with the lowest values observed at the river mouths, especially between transects 5 (Toupeti) to 8 (Ponerihouen), and in the North (transect 11 in Tiwaka rivers), while the highest ones were recorded in the southernmost (transect 1-4) and northernmost parts (transect 12) (Table SI-1; Fig. 2a). $\mathrm{Si}(\mathrm{OH})_{4}$ concentration substantially decreased from rivers $(403.8 \pm 3.5 \mu \mathrm{M})$ to ocean $(4.3 \pm 3.2 \mu \mathrm{M})$, with a maximum recorded in transect 6 in Thio river (Table SI-1; Fig. 2b).

$\mathrm{NO}_{\mathrm{X}}$ concentration presented almost the same spatial distribution as $\mathrm{Chl} a$ concentration except in the northern part where the highest $\mathrm{NO}_{\mathrm{X}}$ concentration was observed between transects 11 and 12, much further north than the Chl a maximum (transects 10-11) (Table SI-1; Fig. 2c, d). Chl $a$ showed a wide range of concentrations $\left(0.02-3.51 \mu g \mathrm{~L}^{-1}\right)$ with strong gradients between river, lagoon and offshore waters all along the eastern coast (Table SI-1; Fig. 2d), except in the North. There, the highest Chl $a$ concentrations were found in transects 10 and 11 at Ponerihouen and Tiwaka rivers, with mean values of $0.99 \pm 0.37$ and $0.81 \pm 0.26 \mu \mathrm{g} \mathrm{L}^{-1}$, respectively, as against a mean value of $0.37 \pm$ $0.17 \mu \mathrm{g} \mathrm{L}^{-1}$ for the whole eastern coast. Mean TOC concentration in the eastern coast was $79.9 \pm 9.1 \mu \mathrm{M}$ with the highest concentrations observed in the northern part. No trend in TOC concentration was found from rivers to offshore waters (Table SI-1; Fig. 2e).

LNA and total bacteria abundances displayed the same spatial distribution with maxima found in transects 10 and 11 (Ponerihouen and Touho) (Table SI-1; Fig. 3b, f). LNA accounted for 52 to $69 \%$ of total bacteria for the whole dataset. The highest abundances of HNA bacteria were noted between transects 10-11, and in coastal stations of transect 6 to 8 (Table SI-1; Fig. 3e). Synechococcus were the most abundant in transects 10 and 11, as Chl $a$ concentration. SynFL2- and SynFL2
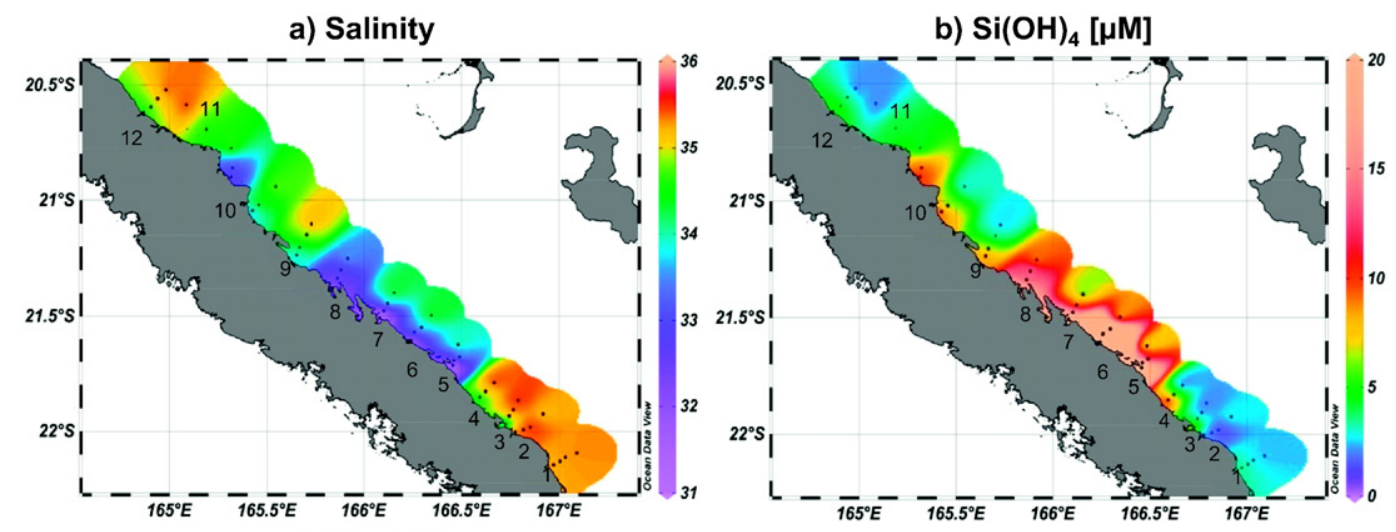

c) $\mathrm{NO}_{x}[\mu \mathrm{M}]$

d) $\mathrm{Chl} \mathrm{a}\left[\mu \mathrm{g} \mathrm{L}^{-1}\right]$
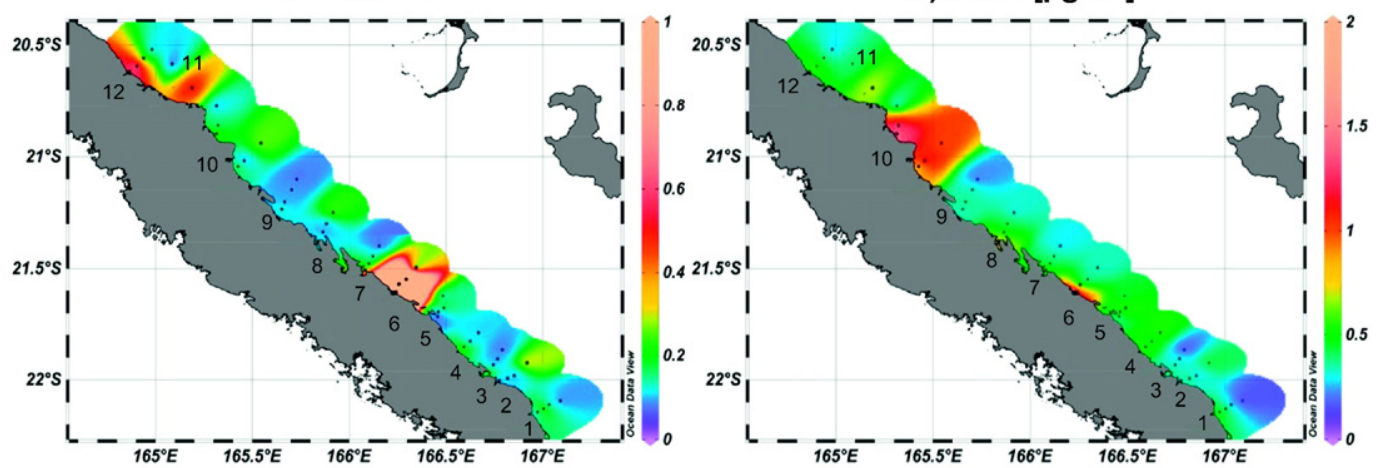

e) TOC $[\mu \mathrm{M}]$

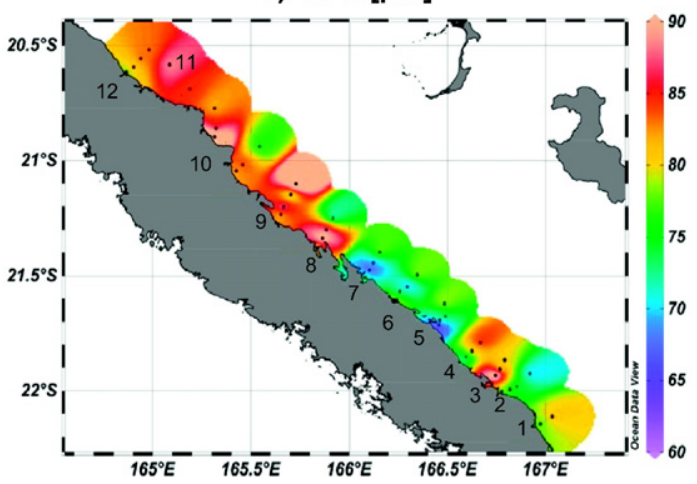

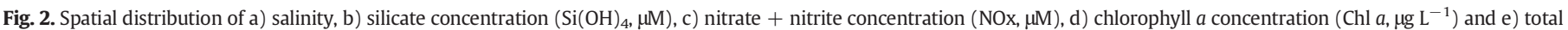

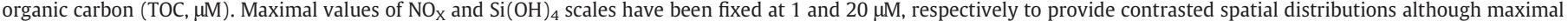
concentrations are of 20.9 and $406.3 \mu \mathrm{M}$, respectively (see Table SI-1). Ocean Data View software version 4.6.5, Schlitzer, R., http://odv.awi.de, 2014. 

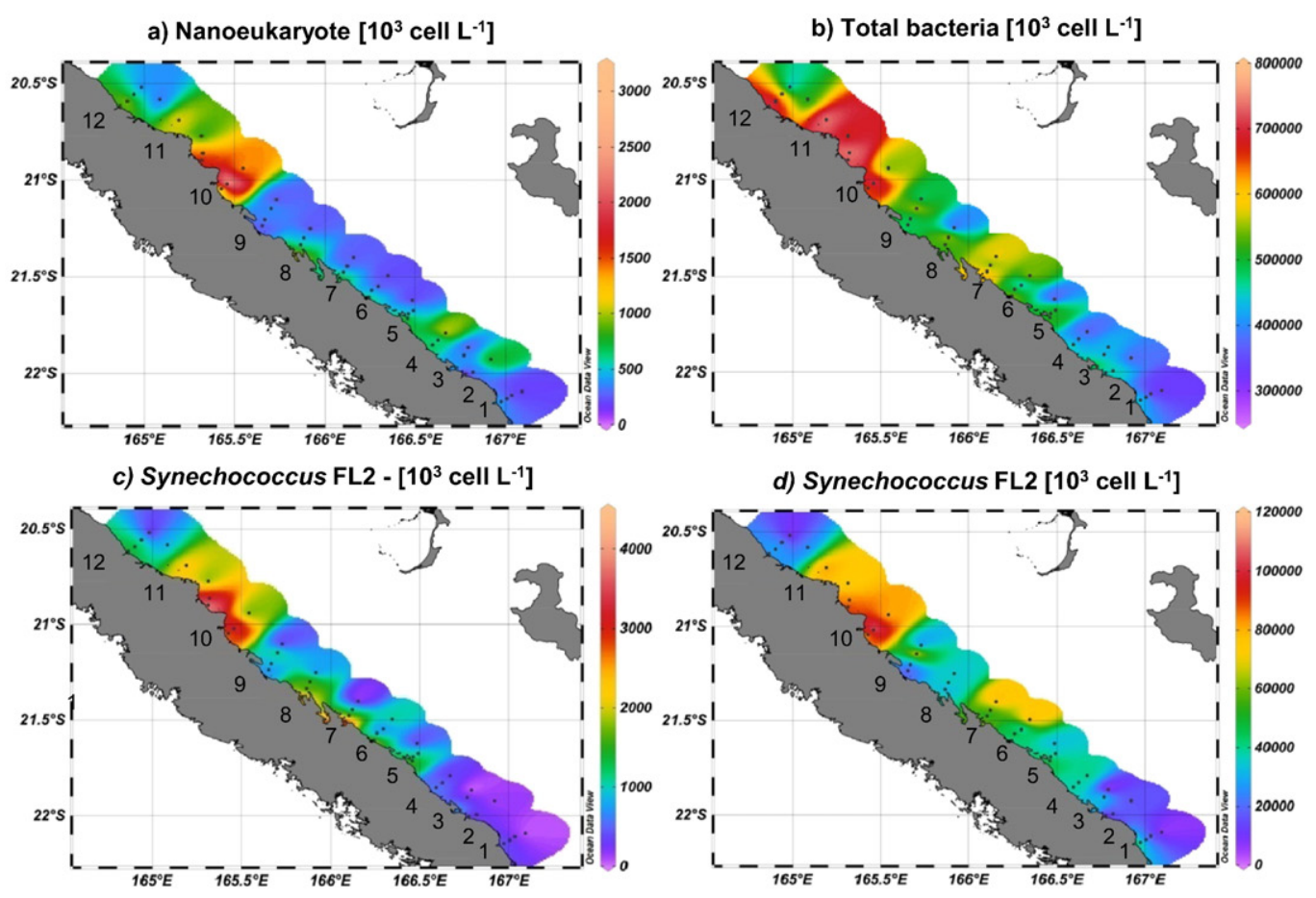

e) HNA bacteria $\left[10^{3}\right.$ cell L-1]

f) LNA bacteria $\left[10^{3}\right.$ cell $\left.\mathrm{L}^{-1}\right]$

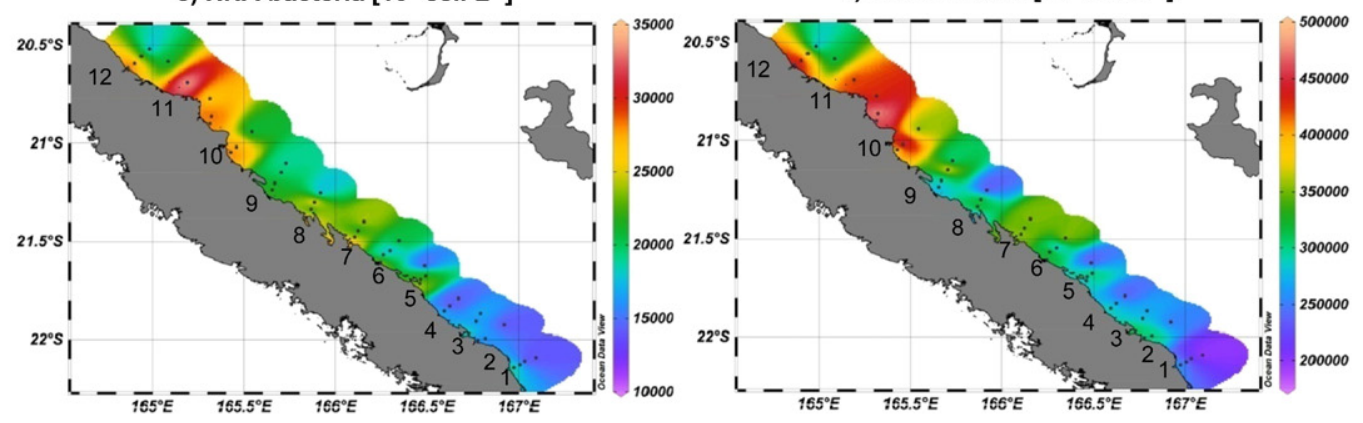

g) Crocosphaera $\left[10^{3}\right.$ cell L-1 $]$

h) Prochlorococcus $\left[10^{3}\right.$ cell L-1]

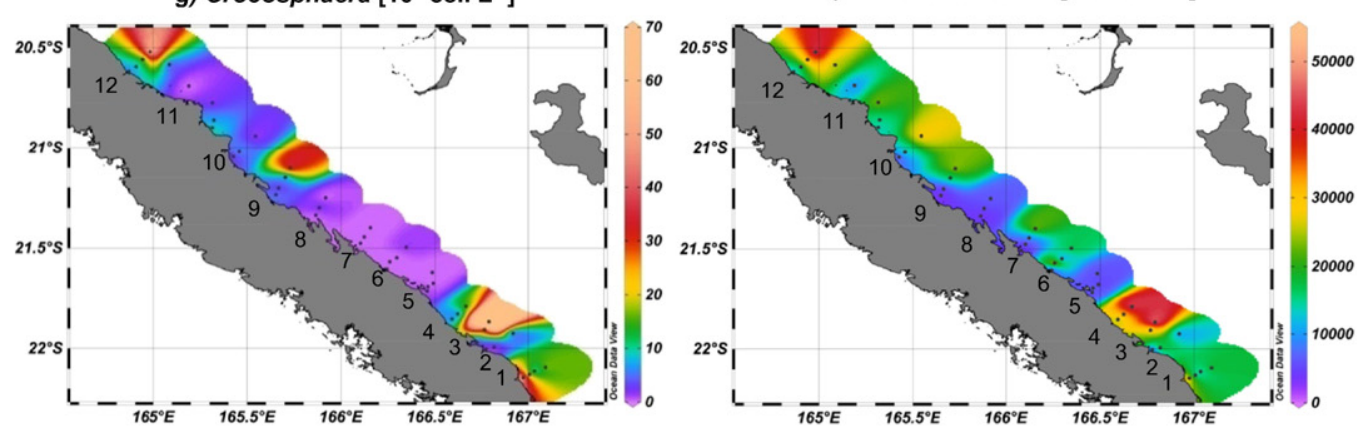

Fig. 3. Spatial distribution of abundances of a) nanoeukaryotes, b) total bacteria, c) Synechococcus FL2-, d) Synechococcus FL2, e) HNA bacteria, f) LNA bacteria, g) Crocosphaeras, and h) Prochlorococcus (in $10^{3}$ cell L ${ }^{-1}$ ). Ocean Data View software version 4.6.5, Schlitzer, R., http://odv.awi.de, 2014.

presented a different pattern, SynFL2- being relatively more abundant at the coast than SynFL2 (Table SI-1; Fig. 3c, d). NanoEuk showed a spatial distribution similar to those of $\mathrm{Chl} a$, Synechococcus cyanobacteria and PicoEuk (Table SI-1; Fig. 3a, c, d). Contrary to other bacteria identified, Proc and Croc-spp. were more abundant in oceanic waters, with the highest concentrations observed in the northernmost and southernmost parts of the eastern coast, especially at transect 3 (Ouinné Bay) (Table SI-1; Fig. 3g, h).

\subsection{Trace metal concentrations}

The highest concentrations of dissolved metals were found in the southern part, with an increasing concentration of $\mathrm{Ni}>\mathrm{Mn}>\mathrm{Co}>\mathrm{Cu}$ (Table SI-2; Fig. 4a-d). Ni concentrations reached a maximum of 24.7 $\mu \mathrm{g} \mathrm{L}{ }^{-1}$ in transect 3 (ST1, ST2, S7) in Ouinné river and were elevated at Thio (transect 6, ST16-ST19, S39), Canala (transect 7, ST14, S33, S34) and Kouaoua (transect 8, ST13 and S28) (Table SI-2; Fig. 4a). The 


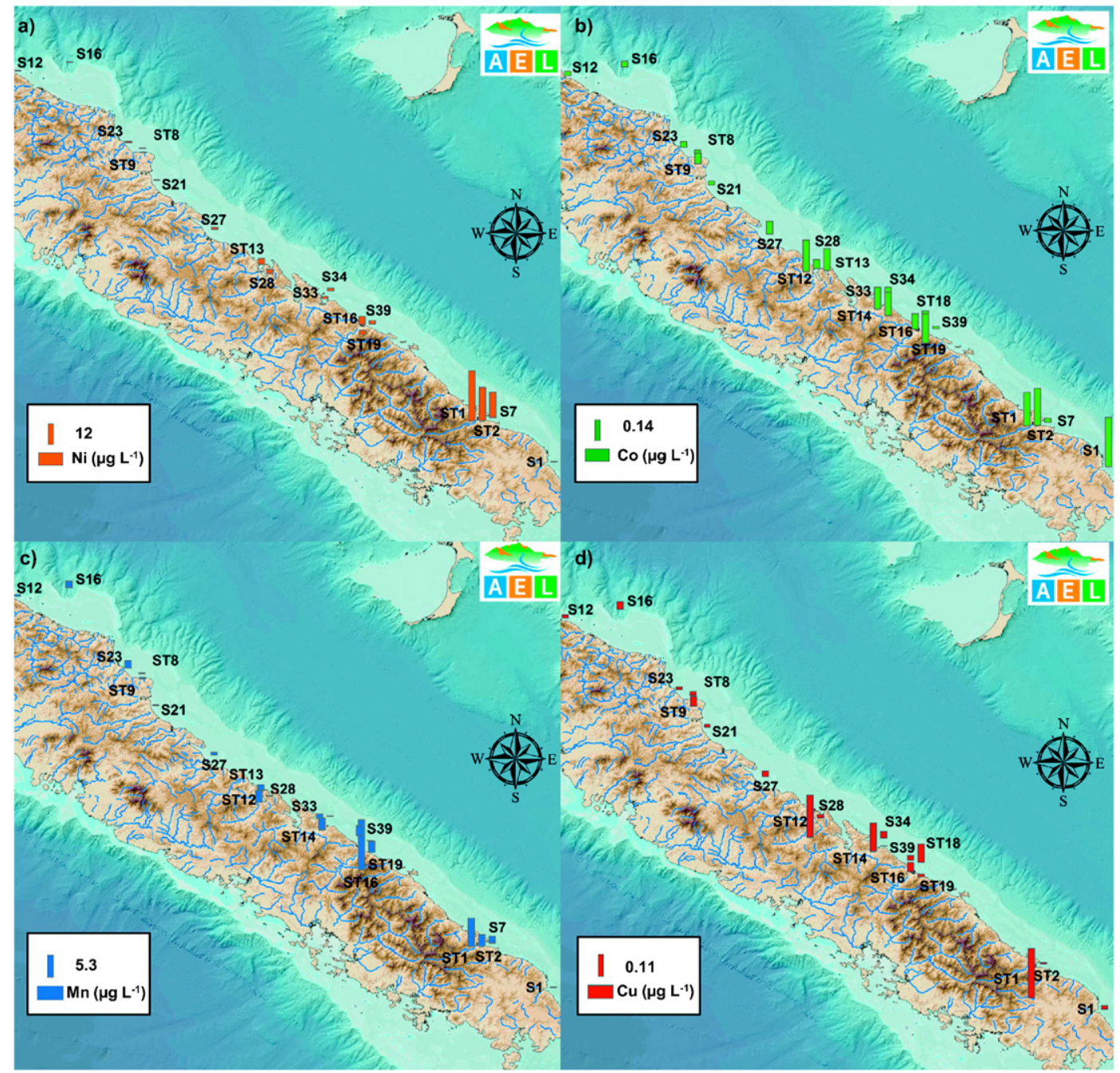

Fig. 4. Spatial distribution of dissolved a) nickel (Ni), b) cobalt (Co), c) manganese (Mn) and d) copper (Cu) (in $\left.\mu g \mathrm{~L}^{-1}\right)$. Maps were plotted with ArcGIS.

maximal Ni concentration measured here $\left(24.7 \mu \mathrm{g} \mathrm{L}^{-1}\right)$ is relatively close to the maximum allowable concentration for environmental quality standards (MAC-EQS) of Ni and related compounds in surface waters defined by the European Union Water Framework Directive (WFD, 2013/39/EU) (i.e., $34 \mu \mathrm{L} \mathrm{L}^{-1}$ ). This shows that Ni concentrations may potentially impact biota in this ecosystem. The highest concentrations of $\mathrm{Co}, \mathrm{Mn}$ and $\mathrm{Cu}$ were observed in the same transects where are situated mining extraction areas (transects 6 to 8; Figs. 1, $4 \mathrm{~b}-\mathrm{d}$ ) and where $37 \%$ of the soil is highly eroded (transect 3 ), as a recent study by the Environmental Observatory of New Caledonia, 2015 determined.

\subsection{Spatial distribution of CDOM absorption properties}

$a_{350}$ ranged from 0.06 to $2.38 \mathrm{~m}^{-1}$ (detection limit of $0.05 \mathrm{~m}^{-1}$ ) with the highest values $\left(>0.15 \mathrm{~m}^{-1}\right)$ recorded in the northern part in river and coastal stations (Table SI-1; Fig. 5a). A large plume of elevated $a_{350}\left(>0.40 \mathrm{~m}^{-1}\right)$ was found in transects 6 and 11 , as a result of the flushing of Thio and Tiwaka rivers expanding over the barrier reef (Fig. 5a). The other transects presented a decreasing gradients of $a_{350}$ from rivers to ocean passages. $\mathrm{S}_{275-295}$ (ranging from 0.002 to $0.112 \mathrm{~nm}^{-1}$ ) and SR (ranging from 0.07 to 7.90 ) increased from rivers to oceanic waters (Table SI-1; Fig. 5b, c). SUVA 254 varied between 0.97 and $2.97 \mathrm{~L} \mathrm{mg} \mathrm{C}-1 \mathrm{~m}^{-1}$. Like $a_{350}$, it decreased from rivers to ocean except in the South (transect 1 to 4 ) (Table SI-1; Fig. 5d).

\subsection{CDOM fluorescent components}

Four CDOM fluorescent components ( $\mathrm{C} 1-\mathrm{C} 4)$ were identified by the PARAFAC model validated on 151 EEM samples. The spectral characteristics of C1-C4 are presented in Fig. SI-1 and compared to fluorescent components reported in the literature (Table 2). C1 and C3 were analogous to the group of protein-like fluorophores, precisely to the tyrosinelike fluorophore for C1 and the tryptophan-like fluorophore for C3. C2 corresponded to humic-like according to the literature (Table 2). C4, very close to C1 (Fig. SI-1; Table 2), is denoted hereafter as tyrosine 2like fluorophore.

\subsection{Spatial distribution of CDOM fluorescent components}

Fig. 6 shows the spatial distribution of the four CDOM fluorescent components along the eastern coast. Tyrosine-like (C1) and humiclike (C2) fluorophores displayed similar spatial distributions, with the highest fluorescence intensities observed in rivers around transects 57 (11.9-21.5 QSU for C1 and 24.0 for C2) and transects 9-11 (12.9 QSU for C1 and 26.3 QSU for C2), where respectively the Thio and Tiwaka/Ponerihouen river flows strongly impacted the lagoon after a strong rain event (10 and 12-13 March). Globally, C1 and C2 fluorescence intensities decreased from the coast to offshore waters (Table SI-1; Fig. 6a, b). Tryptophan-like (C3) fluorophore exhibited a different pattern with the highest fluorescence intensities found in lagoon 
a) $a_{350}\left[\mathrm{~m}^{-1}\right]$

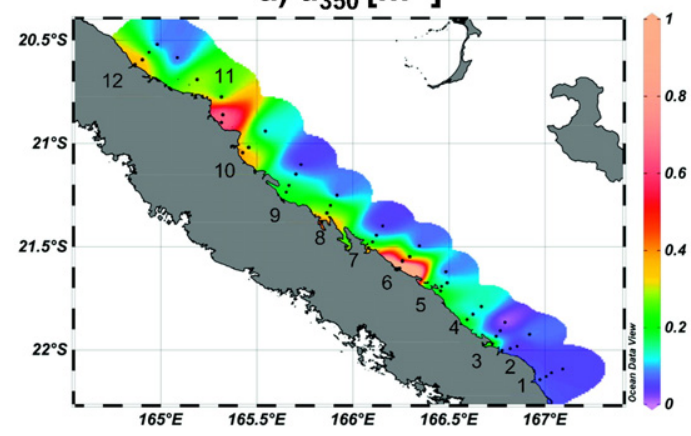

c) $\mathrm{SR}$

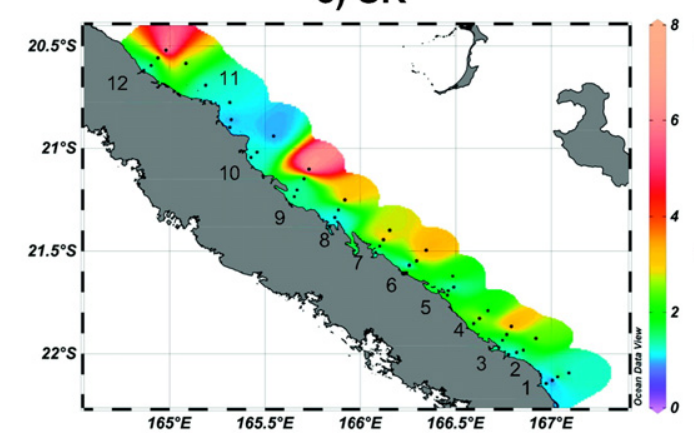

b) $\mathrm{S}_{275-295}\left[\mathrm{~nm}^{-1}\right]$

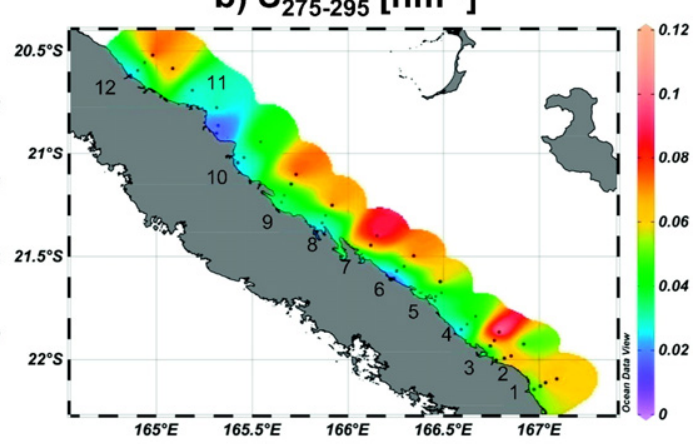

d) SUVA ${ }_{254}\left[\mathrm{~L} \mathrm{mg}^{\left.-\mathrm{CC}^{-1} \mathrm{~m}^{-1}\right]}\right.$

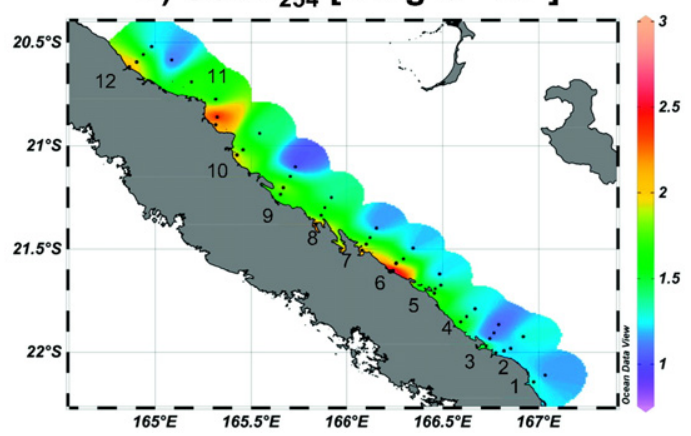

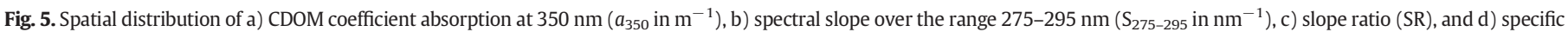

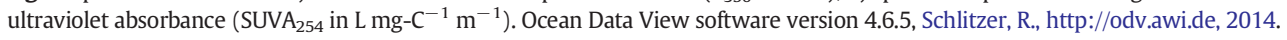

waters, in transect 5 (56.7 QSU) and transect 11 (30.7 QSU) when samples were collected at high tide (Table SI-1; Fig. 6c). Plumes of tryptophan-like material from the barrier reef to the coast were recorded during high tide (Table 1 ). Contrary to the other fluorophores, the tyrosine 2-like (C4) component did not display any specific pattern (increase or decrease) along the river-coastoffshore gradient, but rather recorded its highest fluorescence intensities in the northernmost and southernmost parts of the eastern coast (Table SI-1; Fig. 6d).

\subsection{Relationships between CDOM, biogeochemical and biological parameters}

PCA (a) was conducted with salinity, biogeochemical parameters, plankton communities and CDOM parameters on coastal, lagoon and oceanic stations ( 47 samples). The correlation circle and the projection of samples on the first factorial plane (F1 versus F2) are shown (Fig. 7a, b). F1, which explained $38 \%$ of the total variability within samples, was positively correlated to $\mathrm{a}_{350}, \mathrm{SUVA}_{254}$, humic- and tyrosine-like

Table 2

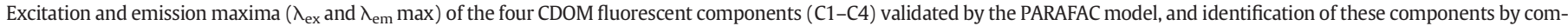
parison with the literature data.

\begin{tabular}{|c|c|c|c|c|c|c|c|c|c|}
\hline \multicolumn{4}{|c|}{ This study } & \multicolumn{6}{|l|}{ Previous studies } \\
\hline Comp & $\begin{array}{l}\lambda_{\mathrm{ex}} \\
(\mathrm{nm})\end{array}$ & $\begin{array}{l}\lambda_{\mathrm{em}} \\
(\mathrm{nm})\end{array}$ & Type & Comp. & $\lambda_{\mathrm{ex}}(\mathrm{nm})$ & $\begin{array}{l}\lambda_{\mathrm{em}} \\
(\mathrm{nm})\end{array}$ & Ref. & Type & Possible origin in natural aquatic water \\
\hline \multirow[t]{5}{*}{$\mathrm{C} 1$} & 220 & 304 & Tyrosine-like & $\mathrm{C} 1$ & 275 & $<300$ & 1 & Tyrosine-like & Autochthonous (heterotrophic prokaryotes or \\
\hline & $(275)$ & & & Component 8 & 275 & 304 & 2 & & phytoplankton) \\
\hline & & & & $\mathrm{B}$ & $225(275)$ & 304 & 3 & & \\
\hline & & & & B2 & $270-280$ & $304-310$ & 4 & & \\
\hline & & & & $\mathrm{C} 1-\mathrm{M}$ & 275 & 305 & 7 & & \\
\hline \multirow[t]{4}{*}{$\mathrm{C} 2$} & 235 & 460 & Humic-like & A & $230-260$ & $400-480$ & 4 & Humic-like & Terrestrial DOM: agricultural land derived, photo-resistant \\
\hline & & & & $\begin{array}{l}\text { Terrestrial } \\
\text { humic-like }\end{array}$ & $<260$ & 454 & 5 & & product \\
\hline & & & & A & 230 & 476 & 3 & & \\
\hline & & & & GoM3 & $<250$ & 462 & 8 & & \\
\hline \multirow[t]{6}{*}{ C3 } & 230 & 352 & Trytophan-like & $\mathrm{T} 1$ & $220-235$ & $334-360$ & 4 & Tryptophan-like & Autochthonous (heterotrophic prokaryotes or \\
\hline & $(300)$ & & & $\mathrm{T}$ & 280 & 350 & 9 & & phytoplankton) \\
\hline & & & & Tryptophan & $<$ & 358 & 11 & & \\
\hline & & & & & $230(290)$ & & & & \\
\hline & & & & $\mathrm{C} 2$ & $230(280)$ & 340 & 10 & & \\
\hline & & & & Tryptophan-like & $230(280)$ & 352 & 14 & & \\
\hline \multirow[t]{2}{*}{ C4 } & $\begin{array}{l}245 \\
(275)\end{array}$ & 304 & Tyrosine 2-like & $\begin{array}{l}\text { Protein-like } \\
\text { material: B }\end{array}$ & $270-280$ & $300-340$ & 12 & Tyrosine-like & Partially degraded food waste, undigested dietary fibre, etc. \\
\hline & & & & Tyrosine-like: B & 270 & 300 & 13 & & \\
\hline
\end{tabular}

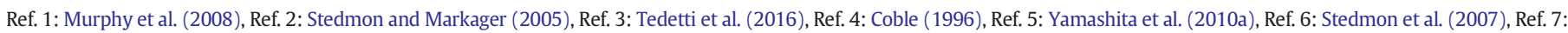

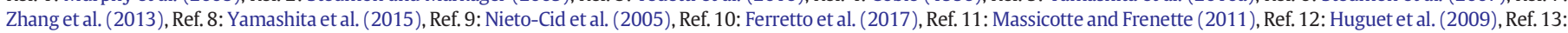
Halim et al. (2013). 
a) C1: Tyrosine-like

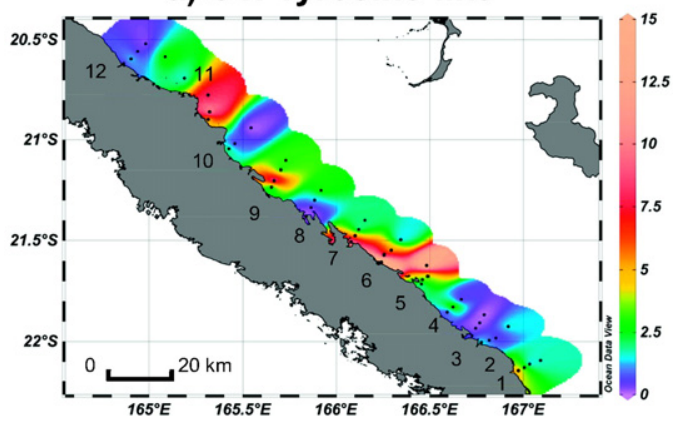

c) C3: Tryptophan-like

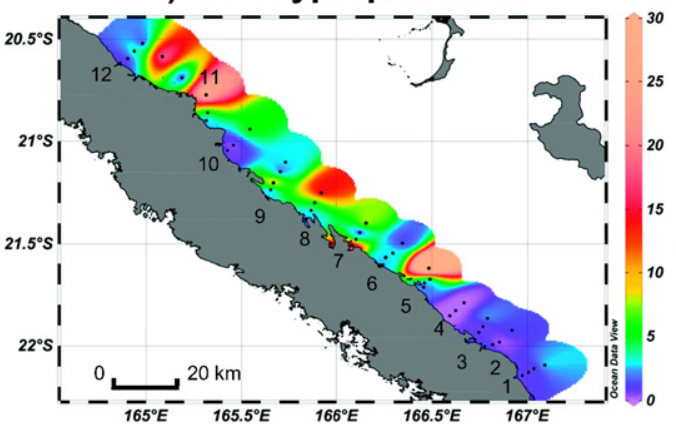

b) C2: Humic-like

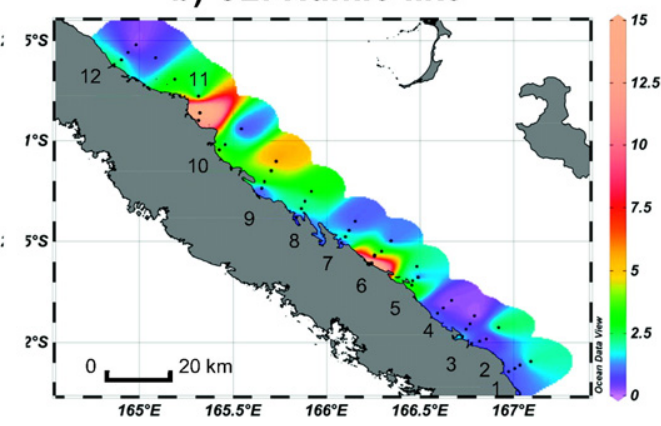

d) C4: Tyrosine2-like

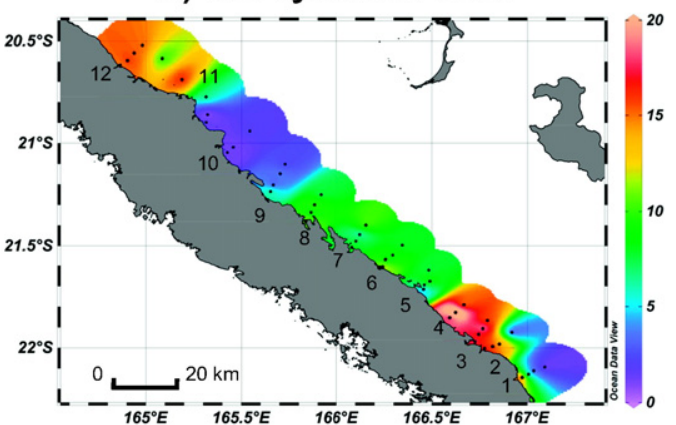

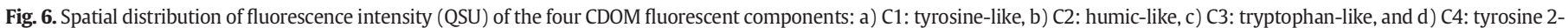
like. Ocean Data View software version 4.6.5, Schlitzer, R., http://odv.awi.de, 2014

fluorophores, nutrients and planktonic abundance, except Proc and Croc. It was negatively related to $\mathrm{SR}, \mathrm{S}_{275-295}$, tryptophan- and tyrosine 2-like fluorophores, salinity and Proc/Croc cyanobacteria. F2 explained

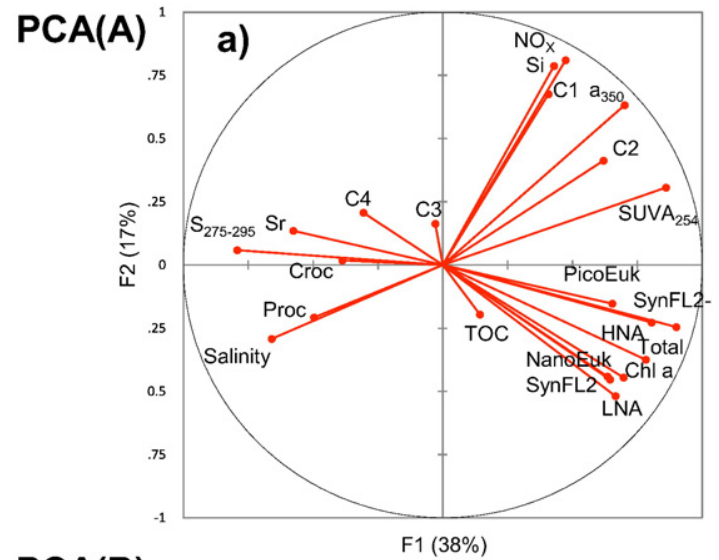

PCA(B)

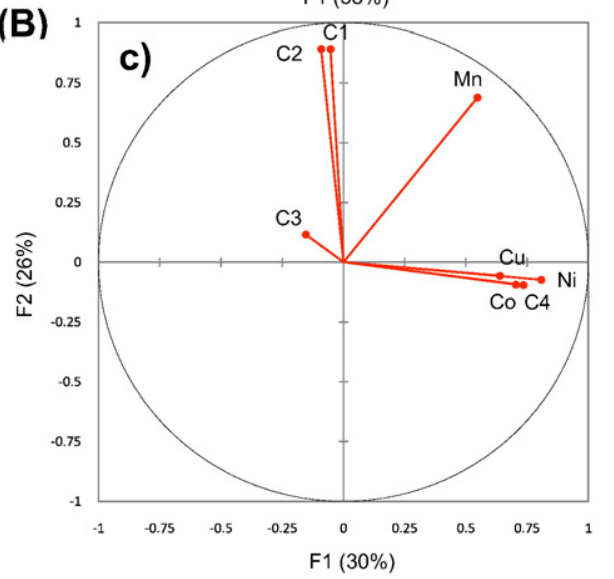

$17 \%$ of the total variability and was positively related to the four fluorophores identified. It was negatively correlated to the bacterial abundance. $a_{350}, \mathrm{SUVA}_{254}$, humic- and tyrosine-like fluorescence
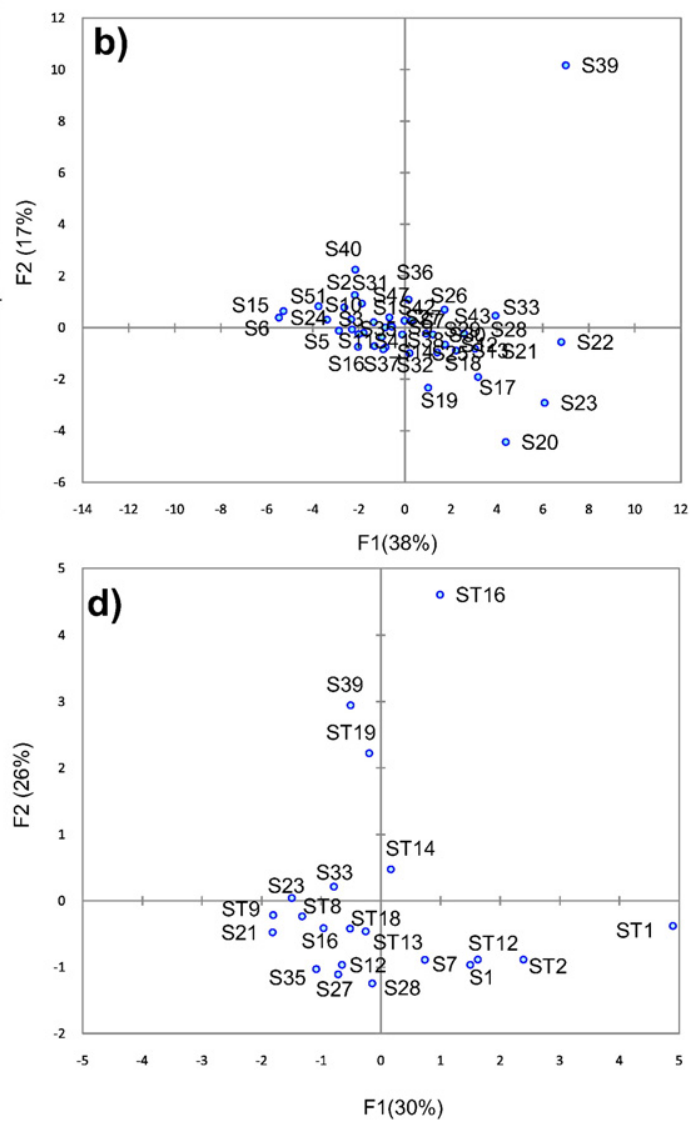

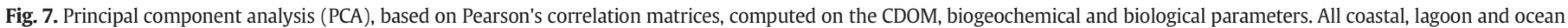
samples $(n=47)$ were used for PCA (a) (a,b), while all (10) river, 9 coastal and 2 lagoon samples $(n=21)$ were used for PCA (b) (c,d). 
intensities, and $\mathrm{NO}_{\mathrm{X}} / \mathrm{Si}(\mathrm{OH})_{4}$ concentrations were significantly positively correlated (Table SI-3). These variables were significantly negatively correlated with $\mathrm{S}_{275-295}$ and salinity, but not correlated with SR (Table SI-3; Fig. 7a). A positive correlation was found between tyrosine- and humic-like fluorophores ( $r=0.63, n=47, p<0.05$ ). Tryptophan-like fluorophore was only correlated to tyrosine-like fluorophore $(r=0.53, n=47, p<0.05)$, while tyrosine 2-like fluorophore was not correlated to the other three fluorophores. Picoand NanoEuk abundances were significantly correlated with $S_{275-295}$ ( $r=-0.56$ and $-0.51, n=47, p<0.05$, respectively). Moreover, the oceanic group Proc, as well as the lagoon groups SynFL2- and PicoEuk presented respectively a positive and a negative correlation with salinity $(r>0.50, n=47, p<0.05)$. Nano and pico-eukaryotes were significantly correlated to phytoplankton biomass ( $\mathrm{Chl} a$ ) with $r=0.81$ and 0.54 , respectively. Bacterial cells (HNA, LNA) were weakly positively correlated to humic-like fluorophore. Contrary to the other fluorophores, tyrosine 2-like component did not display any correlation with other biogeochemical/biological parameters, except with Proc and Syn (Table SI-3; Fig. 7a). The projection of samples on F1 and F2 highlighted a group of stations (S39, S22, S23 and S20) situated at Thio (transect 6), Poindimie (transect 11) and Ponerihouen (transect 10) and positively correlated to parameters describing the F1 axis (Fig. 7b).

PCA(b) was applied to all river stations and some coastal and lagoon stations ( 21 samples) for trace metal concentrations and fluorescence intensities of the four CDOM components (Fig. 7c, d). F1, which explained $30 \%$ of the total variability, was positively related to $\mathrm{Co}, \mathrm{Cu}$ and $\mathrm{Ni}$ concentration and tyrosine 2 -like intensity. It was negatively related to protein-, humic-like fluorophores and other metal concentrations. F2 accounted for $26 \%$ of the total variability and was positively related to Mn concentrations, tyrosine-like (C1), humic-like (C2) and tryptophan-like (C3) fluorophores (Fig. 7c). Relevant Pearson's correlations were observed between tyrosine 2-like fluorophore and the concentrations of $\mathrm{Ni}$ and $\mathrm{Co}(r=0.53$ and $0.54, n=21, p<0.05$, respectively) (Table SI-4). For river and coastal stations, the correlation between humic- and tyrosine-like fluorophores was quite high with $r=$ 0.70 . These two fluorophores presented a significant correlation with Mn $(r=0.46-0.50, n=21, p<0.05)$ but not with Cu concentration (Fig. 7c). The projection of samples presented two groups of stations: the first group (along F1 axis) was composed of stations located at Thio (ST16, S39 and ST19), and the second one (along F2 axis) comprised stations located in the south of the eastern coast (ST1, ST2, S1 and S7) (Fig. 7d).

\section{Discussion}

\subsection{Terrestrial inputs of CDOM}

Salinity measured here in the eastern lagoon of New Caledonia in March (range: 31.1-35.5 excluding river mouths) is comparable to salinity observed in the southwestern lagoon of New Caledonia during the same wet season (range: 34.2-35.6) (Mari et al., 2007; Tedetti et al., 2016). Our biogeochemical data clearly highlights freshwater inputs along the eastern coast, especially at Tiwaka river mouth and between Thio and Ponerihouen (transect 6-8), where a plume of freshwater extending to the coral reef were observed (Fig. 2a). This plume is attributed to the high annual flow rate of Tiwaka river (13.9 $\mathrm{m}^{3} \mathrm{~s}^{-1}$ according to Bonvallo et al., 2013) compared to other rivers draining the eastern coast. Significant negative correlations were found between salinity and $\mathrm{Si}(\mathrm{OH})_{4}$ concentration $(r=-0.53)$, and between salinity and $a_{350}(\mathrm{r}=-0.53)$, humic-like $(r=-0.39)$ and tyrosine-like fluorophores $(r=-0.37, n=47, \mathrm{p}<0.05$ ) (Figs. 2a, b, $5 a, 6 a, b, 7 a$, Table SI-3). These points out terrestrial inputs of CDOM. Humic- and tyrosine-like fluorophores were very likely derived from terrestrial materials, and their presence in the lagoon was amplified by the rainfall events that occurred during our sampling. This humic- like fluorophore is indeed well known to have a terrestrial origin with the microbial degradation of higher plants and soil OM (Coble et al., 2014). $S_{275-295}$ and SUVA $_{254}$ are both usually calculated (Pandi et al., 2014) to characterize CDOM from bacterial degradation (Henderson et al., 2008). SUVA 254 is an indicator of DOM aromaticity (Weishaar et al., 2003) and $S_{275-295}$ a proxy of the CDOM molecular weight. The decrease in $\mathrm{a}_{350}$ and fluorescence intensities of humic- and tyrosine-like fluorophores from rivers to oceanic waters was concomitant to a decrease in $\mathrm{SUVA}_{254}$ and an increase in $\mathrm{S}_{275-295}$ (Figs. 5a, b, d, 6a, b). These modifications of $S_{U V A} 254$ and $S_{275-295}$ values reflect a decrease in the molecular weight and aromaticity of CDOM, and thus a shift from terrestrial to marine CDOM, along the coast-offshore transects (Weishaar et al., 2003; Helms et al., 2008; Fichot and Benner, 2012).

Compared to other areas, such as broad series of continental shelves (Vantrepotte et al., 2015) or the North Aegean Sea (Pitta et al., 2016), our $\mathrm{S}_{275-295}$ values are 3 times higher (but with a methodological difference, the latter values being obtained from double-beam spectrophotometers with small length cuvettes). Helms et al. (2008) suggested that $S_{275-295}$ is a potential indicator of photobleaching and Fichot and Benner (2012) demonstrated that CDOM photodegradation led to an increase in $S_{275-295}$. Hence, $S_{275-295}$ values $>0.03 \mathrm{~nm}^{-1}$ measured here in the lagoon and ocean passes suggest that CDOM was photochemically altered in surface waters. Previous studies usually associated allochthonous humic-like fluorophore with HMW CDOM (Yamashita et al., 2010b; Chen et al., 2011; Pitta et al., 2016). However, humic-like fluorophore found in our work showed a weak correlation with $S_{275}$ 295 and no correlation with SR. Thus, this humic-like component would reflect the presence of CDOM of low and high molecular weight, which would result from the action of photo and bio-transformation on terrestrial material. The chemical structures responsible for the optical signature of this humic-like fluorophore are likely supramolecular assemblies of HMW terrestrial humic matter and of LMW DOM issued from the photochemical and microbial degradation of this terrestrial material. This molecular assembly hypothesis could explain the correlation between tyrosine- and humic-like fluorophores. Indeed, the latter can potentially form supramolecular assemblies based on intramolecular energy transfer requiring small donor to acceptor distances (Jørgensen et al., 2011; Cuss and Guéguen, 2015; Wang et al., 2015). Moreover, the increasing molecular complexity of humic substances increases the intermolecular energy transfer with other fluorescent components like tyrosine-like compound (Mignone et al., 2012).

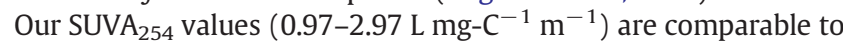
those determined in coastal areas (0.50-4.15 $\mathrm{L} \mathrm{mg-C}^{-1} \mathrm{~m}^{-1}$ ) (Saraceno et al., 2009; Pandi et al., 2014; Xu and Guo, 2017). SUVA 254 is also a good predictor of the metal affinity of DOM in natural waters (Stijn et al., 2011). Regarding their correlation (Table SI-4), humic-like fluorophore and Mn could be associated. As already stated by Pandey et al. (2000), humic DOM hosts high affinity sites for forming coordination compounds with trace metals. It is worth noting that the possible complexation between humic material and Mn could imply a quenching effect on the fluorescence intensities of the humic-like fluorophore, and thus their underestimation (Ryan et al., 1983).

Mn concentrations reached $10.6 \mu \mathrm{g} \mathrm{L}{ }^{-1}$, which is 5 to 10 times higher than the concentrations previously recorded in surface waters of the western lagoon of New Caledonia (0.66-2.5 $\mu \mathrm{g} \mathrm{L} \mathrm{L}^{-1}$; Moreton, 2009). In surface waters, Mn mainly comes from continental runoff, aeolian deposition and continental shelf sediments (Shiller, 1997). Thus, Mn may have allochthonous (river inputs and aerosols) and autochthonous sources (sediments). Indeed, Mn-oxides are reduced during diagenesis processes and associated with the decomposition of $\mathrm{OM}$ in sediment, a potential source of CDOM (Coble et al., 2014). This process could explain high concentrations of Mn in Thio river (low depth) and the release of humic-like material in freshwater settings.

Humic-like fluorophore from shelf sediments could contribute to the pool of fluorescent CDOM in the Thio and Tiwaka coastal areas but more investigations on DOM-POM exchange processes (adsorption/ 
desorption or aggregation/dissolution) are necessary to understand the origin of terrestrial humic-like fluorophore identified in the New Caledonian lagoon as has been already highlighted by He et al. (2016). Humic- and tyrosine-like fluorophores are spatially linked to river runoffs transporting nutrients to enrich the lagoon and induce plankton biomass abundance.

\subsection{Removal of CDOM by biological processes}

Regarding the Chl $a$ concentrations recorded here after a rainfall event (up to $1.44 \mu \mathrm{g} \mathrm{L}^{-1}$; already reported by Tenorio et al., 2005), the eastern lagoon of New Caledonia shows quite a high phytoplankton biomass compared with other tropical reef areas, such as the Réunion Island (0.14-0.32 $\mu \mathrm{g} \mathrm{L}^{-1}$; Tedetti et al., 2011) and Maunalua Bay (Hawaï, 0.06-0.29 $\mathrm{g} \mathrm{L}^{-1}$; Nelson et al., 2015). In this study, tyrosinelike fluorophore was not well correlated to $\mathrm{Chl} a$, suggesting that tyrosine-like fluorophore in the lagoon is not a part of the DOM produced by marine phytoplankton (Romera-Castillo et al., 2010).

In other relevant parts of the lagoon with high fluorescence intensities of tyrosine-like fluorophore ( $>5 \mathrm{QSU}$ ), compared to those reported in the North Pacific Ocean ( $<2.5$ QSU; Yamashita et al., 2010a), this protein-like material could come from the HNA and LNA bacterial degradation of protein/peptides in rivers, which produces amino-acids released in the lagoon through river plumes (Yamashita and Tanoue, 2004; Yamashita et al., 2015). Nevertheless, no significant correlation between tyrosine-like and bacterial abundances was observed. It should be noticed that the fluorescence of tyrosine-like fluorophore could be reduced because of the quenching by tryptophan- and humic-like fluorophores through energy transfer. Indeed, in the case of the supramolecular assemblies hypothesis, intermolecular energy transfers between tyrosine and humic substances are suggested, decreasing the fluorescence intensity of tyrosine-like fluorophore (Wang et al., 2015). This fluorescence inhibition could induce difficulties in the detection of tyrosine-like fluorophore in this study, which may explain of the low correlations between tyrosine-like and others biogeochemical parameters. Mayer et al. (1999) clearly presents the difficulties of accounting for tyrosine-like in the area influenced by the presence of terrestrial derived OM.

Mn could also have a quenching effect on tyrosine-like fluorophore, as suggested by the high correlation between these two variables. A quenching experiment in the laboratory with $\mathrm{Mn}$ and natural CDOM from the eastern coast could reveal the quenching effect of $\mathrm{Mn}$ and its complexation with CDOM fluorophores, reducing its potential toxicity. Previous studies showed the complexing capacity of Mn with fulvic acid and the complexing capacity of $\mathrm{Co}$ and $\mathrm{Cu}$ with protein-like materials (Ryan et al., 1983; Ventry et al., 1991; Plaza et al., 2006; Wu et al., 2010). However, more investigations are necessary to determine the possible ecological impact of natural CDOM on metal bio-availability in the eastern lagoon of New Caledonia. The strong correlations between tyrosine-like fluorophore and river input proxies $\left(\mathrm{a}_{350}, \mathrm{NO}_{\mathrm{x}}\right)$, as well as the absence of correlation with SR and $S_{275-295}$ is consistent with the diversity and the complexity of the tyrosine-like sources.

In previous studies (Coble et al., 2014; Jaffé et al., 2014; Yamashita et al., 2015), tyrosine-like fluorophore has been found to be linked to tryptophan-like material, due to the same origin (produced by microbial degradation in the ocean). In our work, tyrosine- and tryptophan-like fluorophores were slightly correlated. Hence, tyrosine-like fluorophore may have also an autochthonous origin related to biological activity in surface waters. However, as it was already noted, tyrosine-like fluorophore was not correlated to bacterial abundance. So bacterial degradation could be a balance between the consumption and the production of tyrosine-like compounds stimulated by nutrient enrichment. Both processes imply that tyrosine-like fluorophore may be accumulated and subsequently consumed, as a function of nutrient availability (high correlation between tyrosine-like and $\mathrm{NO}_{\mathrm{X}}$ ). Biers et al. (2007) showed a production of protein-like fluorophores during bacterial incubation in seawater when labile sources of nitrogen were added. In this study, it was not possible to discriminate the dominant process between the consumption of labile DOM from rivers and ocean passes and the production of protein-like by bacterial communities because of the potential alteration of fluorescence intensity by the quenching processes.

\subsection{Possible releases of tryptophan-like from coral reef}

Regarding the spatial distribution of tryptophan-like fluorophore, its sources seemed to be essentially autochthonous. Maximal fluorescence intensity of the tryptophan-like component (60 QSU) is similar to that reported in the Southwest Florida Shelf (Mendoza et al., 2012) and is thought to be associated to an in-situ biological production other than bacteria activity. The presence of tryptophan-like fluorophore in the waters surrounding the coral reef could be linked to the biological activity of the coral reef ecosystem, as observed by Nelson et al. (2013) in the Moorea lagoon, French Polynesia. Indeed, the dominant hermatypic coral holobiont Porites spp. in the South Pacific and the microalgae associated exude labile DOC with fluorescent properties similar to those of tryptophan-like material (Nelson et al., 2015), influencing the microbial activity and altering bacterioplankton growth and community structure around coral reefs. Tryptophan-like released in waters surrounding the coral reef would be then subjected to the effect of the tide inducing local seawater inflows and plumes of tryptophan from the open ocean to the coast even though no evidence of relevant maritime influence is obvious.

The high production of tryptophan-like observed between transects 7 to 9 could also be associated with possible nutrient sources to produce a bloom of Trichodesmium (nitrogen fixing cyanobacteria in the Southwestern Tropical Pacific; Dupouy et al., 2011) observed during the cruise outside the barrier reef at passages transect 7 (Kouaoua) and transect 8 (Canala). A high correlation $(r=0.96)$ between the tryptophan consumption and the formation of harmful algal bloom of Karenia brevis has already been observed in the Southwest Florida shelf (Mendoza et al., 2012) and the same process could be occurred as likely in this area to explain the Trichodesmium bloom and the concentrations of tryptophan-like found (0.64-24 QSU). On the contrary, Steinberg et al. (2004) assumed the CDOM production by Trichodesmium, which could also be a source of tryptophan-like fluorophore. More investigations to characterize the production of $\mathrm{CDOM}$ by Trichodesmium are necessary to clearly identify sources of tryptophan-like material in this ecosystem.

\subsection{Possible oceanic origin for tyrosine 2-like fluorophore}

On the eastern coast, a southeastward boundary current flowing between the main island and the Loyalty Islands is called the Vauban Current (Hénin et al., 1984). In the extreme poles of New Caledonia, this current is strongly subjected to short-time variability attributed to tidal, inertial (inertial oscillations period around $32 \mathrm{~h}$ at this latitude), inter-seasonal variability and local forcing, which contributed to generating current anomalies like cyclonic eddies pushing oceanic water in the lagoon and creating a surface mixing of water in the extreme South and the North (Cravatte et al., 2015). Seawater inflows around the southernand northern tips explained the highest salinity observed and the absence of gradient coast -offshore in CDOM and biogeochemical parameters. With regard to its spatial distribution, tyrosine 2-like fluorophore seems to be correlated to the salinity with the highest fluorescence intensities recorded in the extremities of the eastern coast although no significant correlation was found between tyrosine 2-like and salinity. Nevertheless, weak correlations between picocyanobacteria (Syn, Proc) and tyrosine 2-like fluorophores are shown Fig. 7a and Table SI-3. Proc represents the main photosynthetic bacteria in oligotrophic waters (Angly et al., 2016) and is used with Croc-spp. as a proxy of seawater inflow through passes in the lagoon. 
The highest abundance of these bacteria, observed where tyrosine 2like fluorophore displayed its maximal fluorescence intensities (transect 3 ), could indicate a link between the abundance of cyanobacteria and the potential effect of tyrosine 2-like fluorophore on its growth. The weak negative correlation of tyrosine 2-like fluorophore with Synechococcus, dominant in coastal areas, corroborates the potential allochthonous source of this fluorophore. However, in this study the spatial pattern was coupled to the temporal variability during the cruise ( 2 weeks) which complicated the analysis of Pearson correlations between all parameters. This fact could explain that correlations between parameters are not clearly identified.

Tyrosine 2-like could be a protein-like fluorophore with binding properties with $\mathrm{Ni}$ and $\mathrm{Co}$, in the light of its fluorescence spectral properties closed to those of tyrosine-like fluorophore (Hernes et al., 2009; Huguet et al., 2009). More investigations are necessary to clearly identify the allochthonous sources of tyrosine 2-like and understand its binding properties with trace metals. The stability constant of complexation between tyrosine 2-like fluorophore and metal may help to predict the behavior of these complexes in the environment and also its strength. Thus, tyrosine 2-like fluorophore could be considered as an organic ligand which may render $\mathrm{Ni}$ and $\mathrm{Co}$ immobile, thereby helping in detoxification processes in the lagoon (Pandey et al., 2000).

At the extremities of the eastern coast, high altitude forest ( $1500 \mathrm{~m}$ ) landscapes are predominant and could contribute to aerosol deposition into enriched surface waters. This potential contribution in tyrosine 2like sources involves windy conditions (wind $<22$ nt during the cruise). More investigations of aerosol deposition along the eastern coast of New Caledonia, as recently reported by Maki et al. (2016) and Chien et al. (2016), could explain the input of organic compounds in this coral reef ecosystems.

\section{Conclusion}

This study underlines the diversity of CDOM properties along the eastern coast of New Caledonia, a coral reef area strongly impacted by river discharges and soil leaching. $a_{350}$ reveals the strong impact of river discharges which impact the lagoon until the coral reef at rainy weather. Regarding $S_{275-295}$ and the globally low $\mathrm{SUVA}_{254}$, CDOM along the eastern coast is subjected to photo degradation with a low aromaticity. Specific CDOM is identified: tyrosine-like, humic-like, tryptophan-like and tyrosine2-like. The diversity in CDOM fluorescent components, the complexity of their spatial distribution and their relationships with biogeochemical parameters, plankton communities and trace metal concentrations clearly highlight the heterogeneity of CDOM sources in the eastern lagoon: (1) river inputs in the lagoon, higher during rain events, (2) biological/microbial degradation of OM, (3) coral reef barrier releases, and (4) oligotrophic oceanic waters entering the lagoon through passes. All these sources are influenced by tide, eddies and meteorological conditions. Further, in this context of mining factory, binding properties between trace metals and CDOM may modify the spectral properties of the latter and therefore add complexity to the identification of its sources. To better understand the impact of trace metals in the lagoon, binding properties between $\mathrm{Ni}$, Co and $\mathrm{Mn}$ and CDOM could be assessed via fluorescence quenching experiments (Plaza et al., 2006; Stijn et al., 2011; Wu et al., 2010). Moreover, our study suggests that coral reef activity could release tryptophan-like material. Haas et al. (2013) have shown that DOC exudates are released by the dominant benthic primary producers (calcifying and noncalcifying corals). Nevertheless, the production of tryptophan-like fluorophore from corals has not been accurately quantified so far. The determination of DOC and CDOM fluxes from coral reefs could be assessed in future laboratory experiments. The determination of relationships between the nature of fluorescent exudates released by corals and associated macroalgae and the taxonomic criteria of these organisms would contribute to the better knowledge of biological CDOM sources in tropical lagoons. Finally, with respect to the influence of meteorological conditions on CDOM distribution, seasonal variations of CDOM along the gradient river-ocean should be investigated in the future. CDOM data thus obtained at spatial and seasonal scales could be included in a coupled hydrodynamic/biogeochemical model at meso-scale dedicated to the understanding of the lagoon-ocean interactions in the South West of New Caledonia (Fuchs et al., 2012, 2013).

\section{Acknowledgements}

The CALIOPE cruises were funded by CNRS-INSU EC2CO TREMOLO and IRD-MIO Action Sud projects. The authors warmly thank AEL (Laboratoire d'analyse et d'environnement marin de Nouvelle Calédonie) and the Director J.M. Fernandez for providing their private ISO-9001 protocols and materials for trace metal analysis. We acknowledge the captain and crew of the R/V Alis. We are grateful to S. Lal and T. Garnier for their help during sampling. We also thank P. Gérard and the US-IMAGO laboratory for their technical support and their ICP-MS analyses. G. Durrieu and PROTEE laboratory are greatly thanked for DOC analyses. We also very warmly thank Franscesca Buscioni, Ricardo Rodofo Metalpa and Fanny Houlbreque from UMR Entropie in New Caledonian IRD center for their precious advices and support in the redaction of this paper. To conclude, we appreciate the comments and suggestions of four anonymous reviewers that allowed substantially improving the quality of the manuscript.

\section{Appendix A. Supplementary data}

Supplementary data to this article can be found online at https://doi. org/10.1016/j.scitotenv.2017.10.261.

\section{References}

Andre, S., Pelletier, B., 2009. A reappraisal of the diversity of geomorphological and genetic processes of New Caledonian coral reefs: a synthesis from optical remote sensing, coring and acoustic multibeam observations. Coral Reefs:691-707 https://doi.org/ 10.1007/s00338-009-0503-y.

Andrew, A.A., Del, R., Subramaniam, A., Blough, N.V., 2013. Chromophoric dissolved organic matter (CDOM) in the Equatorial Atlantic Ocean: optical properties and their relation to CDOM structure and source. Mar. Chem. 148:33-43. https://doi.org/ 10.1016/j.marchem.2012.11.001.

Angly, F.E., Heath, C., Morgan, T.C., Tonin, H., Rich, V., Schaffelke, B., Bourne, D.G., Tyson, G.W., 2016. Marine microbial communities of the Great Barrier Reef lagoon are influenced by riverine floodwaters and seasonal weather events. PeerJ 4, e1511. https:// doi.org/10.7717/peerj.1511.

Barth, A., Alvera-Azcárate, A., Troupin, C., Ouberdous, M., Beckers, J.M., 2010. A web interface for griding arbitrarily distributed in situ data based on Data-Interpolating Variational Analysis (DIVA). Adv. Geosci. 28:29-37. https://doi.org/10.5194/adgeo-28-292010.

Benner, R., Louchouarn, P., Amon, R.M.W., 2005. Terrigenous dissolved organic matter in the Arctic Ocean and its transport to surface and deep waters of the North Atlantic. Glob. Biogeochem. Cycles 19:1-11. https://doi.org/10.1029/2004GB002398.

Biers, E.J., Zepp, R.G., Moran, M.A., 2007. The role of nitrogen in chromophoric and fluorescent dissolved organic matter formation. Mar. Chem. 103:46-60. https://doi.org/ 10.1016/j.marchem.2006.06.003.

Biscéré, T., Lorrain, A., Rodolfo-Metalpa, R., Gilbert, A., Wright, A., Devissi, C., Peignon, C., Farman, R., Duvieilbourg, E., Payri, C., Houlbrèque, F., 2017. Nickel and ocean warming affect scleractinian coral growth. Mar. Pollut. Bull. 120:250-258. https://doi.org/ 10.1016/j.marpolbul.2017.05.025.

Bonvallot, J., Gay, J.-C., Habert, E., 2013. Atlas de la Nouvelle-Calédonie IRD éditions (Nouméa ISBN-10: 2709917408 ISBN-13: 978-2709917407).

Cao, F., Medeiros, P.M., Miller, W.L., 2016. Optical characterization of dissolved organic matter in the Amazon River plume and the adjacent ocean: examining the relative role of mixing, photochemistry, and microbial alterations. Mar. Chem. 186: 178-188. https://doi.org/10.1016/j.marchem.2016.09.007.

Carlson, C.A., Hansell, D.A., 2015. DOC sources, sinks, reactivity, and budgets. In: Hansell, D.A., Carlson, C.A. (Eds.), Biogeochemistry of Marine Dissolved Organic Matter, 2nd Edition Academic Press, pp. 65-126.

Carstea, E.M., Bridgeman, J., Baker, A., Reynolds, D.M., 2016. Fluorescence spectroscopy for wastewater monitoring: a review. Water Res. 95:205-219. https://doi.org/10.1016/ j.watres.2016.03.021.

Chen, H., Zheng, B., Song, Y., Qin, Y., 2011. Correlation between molecular absorption spectral slope ratios and fluorescence humification indices in characterizing CDOM Aquat. Sci. 73:103-112. https://doi.org/10.1007/s00027-010-0164-5.

Chen, M., Kim, S.-H., Jung, H.-J., Hyun, J.-H., Choi, J.H., Lee, H.-J., Huh, I.-A., Hur, J., 2017. Dynamics of dissolved organic matter in riverine sediments affected by weir 
impoundments: production, benthic flux, and environmental implications. Water Res. 121:150-161. https://doi.org/10.1016/j.watres.2017.05.022.

Chien, C.-T., Mackey, K.R.M., Dutkiewicz, S., Mahowald, N.M., Prospero, J.M., Paytan, A. 2016. Effects of African dust deposition on phytoplankton in the western tropical Atlantic Ocean off Barbados. Glob. Biogeochem. Cycles 30:716-734. https://doi.org/ 10.1002/2015GB005334.

Chisholm, S.W., 2000. Stirring times in the southern ocean. Nature 407:685-687. https:// doi.org/10.1038/35037696.

Cluzel, D., Aitchison, J.C., Picard, C., 2001. Tectonic accretion and underplating of mafic terranes in the Late Eocene intraoceanic fore-arc of New Caledonia (Southwest Pacific) Geodynamic implications. Tectonophysics 340:23-59. https://doi.org/10.1016/ S0040-1951(01)00148-2.

Coble, P.G., 1996. Characterization of marine and terrestrial DOM in seawater using excitation-emission matrix. Spectroscopy 51, 325-346.

Coble, P.G., Lead, J., Baker, A., Reynolds, D.M., Spencer, R.G.M., 2014. Aquatic organic matter fluorescence. first editCambridge Environmental Chemistry Series (New York).

Cravatte, S., Kestenare, E., Eldin, G., Ganachaud, A., Lefèvre, J., Marin, F., Menkes, C., Aucan, J., 2015. Regional circulation around New Caledonia from two decades of observations. J. Mar. Syst. 148:249-271. https://doi.org/10.1016/j.jmarsys.2015.03.004.

Cuss, C.W., Guéguen, C., 2015. Relationships between molecular weight and fluorescence properties for size-fractionated dissolved organic matter from fresh and aged sources. Water Res. 68:487-497. https://doi.org/10.1016/j.watres.2014.10.013.

Del Vecchio, R., Blough, N.V., 2002. Photobleaching of chromophoric dissolved organic matter in natural waters: kinetics and modeling. Mar. Chem. 78, 231-253.

Dublet, G., Juillot, F., Morin, G., Fritsch, E., Fandeur, D., Ona-Nguema, G., Brown, G.E., 2012. Ni speciation in a New Caledonian lateritic regolith: a quantitative X-ray absorption spectroscopy investigation. Geochim. Cosmochim. Acta 95:119-133. https://doi.org/ 10.1016/j.gca.2012.07.030

Dublet, G., Juillot, F., Morin, G., Fritsch, E., Fandeur, D., Brown Jr, G.E., 2015. Goethite aging explains Ni depletion in upper units of ultramafic lateritic ores from New Caledonia. Geochim. Cosmochim. Acta 160:1-15. https://doi.org/10.1016/j.gca.2015.03.015.

Dupouy, C., Neveux, J., Dandonneau, Y., Westberry, T.K., Caledonia, N., 2011. An algorithm for detecting Trichodesmium surface blooms in the South Western Tropical Pacific. Biogeosciences 8:3631-3647. https://doi.org/10.5194/bg-8-3631-2011.

Dupouy, C., Röttgers, R., Tedetti, M., Martias, C., Murakami, H., 2014. Influence of CDOM and particle composition on ocean color of the eastern New Caledonia lagoon during the CALIOPE cruises. SPIE 9261:2-9. https://doi.org/10.1117/12.2073309.

Environmental Observatory of New Caledonia, 2015. Numerical cartographic study from satellite data. http://www.oeil.nc/fr/actualites/la-vallee-de-la-ouinne-passee-laloupe (accessed 07.08.17).

Fandeur, D., Juillot, F., Morin, G., Olivi, L., Cognigni, A., Webb, S.M., Brown, G.E.X., 2009. Evidence for oxidation of $\mathrm{Cr}(\mathrm{III})$ to $\mathrm{Cr}(\mathrm{VI})$ by Mn-oxides in a lateritic regolith developed on serpentinized ultramafic rocks of New Caledonia. Environ. Sci. Technol. 43: 7384-7390. https://doi.org/10.1021/es900498r.

Fernandez, J.M., Ouillon, S., Chevillon, C., Douillet, P., Fichez, R., Le Gendre, R., 2006. A combined modelling and geochemical study of the fate of terrigenous inputs from mixed natural and mining sources in a coral reef lagoon (New Caledonia). Mar. Pollut. Bull. 52:320-331. https://doi.org/10.1016/j.marpolbul.2005.09.010.

Ferretto, N., Tedetti, M., Guigue, C., Mounier, S., Raimbault, P., Goutx, M., 2017. Spatiotemporal variability of fluorescent dissolved organic matter in the Rhône Rive delta and the Fos-Marseille marine area (NW Mediterranean Sea, France). Environ. Sci. Pollut. Res. 24:4973-4989. https://doi.org/10.1007/s11356-016-8255-z.

Fichot, G., Benner, R., 2012. The spectral slope coefficient of chromophoric dissolved organic matter (S 275-295) as a tracer of terrigenous dissolved organic carbon in river-influenced ocean margins. Limnol. Oceanogr. 57:1453-1466. https://doi.org/ 10.4319/lo.2012.57.5.1453.

Fuchs, R., Dupouy, C., Douillet, P., Caillaud, M., Mangin, A., Pinazo, C., 2012. Modelling the impact of a La Niña event on a South West Pacific lagoon. Mar. Pollut. Bull. 64: 1596-1613. https://doi.org/10.1016/j.marpolbul.2012.05.016.

Fuchs, R., Pinazo, C., Douillet, P., Fraysse, M., Grenz, C., Mangin, A., Dupouy, C., 2013. Modelling ocean-lagoon interaction during upwelling processes in the South West of New Caledonia. Estuar. Coast. Shelf Sci. 135:5-17. https://doi.org/10.1016/ j.ecss.2013.03.009.

Gao, Z., Guéguen, C. 2016. Size distribution of absorbing and fluorescing DOM in Beaufort Sea, Canada Basin. Deep-Sea Res. I Oceanogr. Res. Pap. 121:30-37. https://doi.org/ 10.1016/j.dsr.2016.12.014

Gauthier, T.D., Shane, E.C., Guerin, W.F., Seitz, W.R., Grant, C.L., 1986. Fluorescence quenching method for determining the equilibrium constants for polycyclic aromatic hydrocarbons binding to dissolved humic materials. Environ. Sci. Technol. 20, $1162-1166$.

Guigue, C., Tedetti, M., Dang, D.H., Mullot, J.-U., Garnier, C., Goutx, M., 2017. Remobilization of polycyclic aromatic hydrocarbons and organic matter in seawater during sediment resuspension experiments from a polluted coastal environment: insights from Toulon Bay (France). Environ. Pollut. 229:627-638. https://doi.org/10.1016/ j.envpol.2017.06.090.

Haas, A.F., Nelson, C.E., Rohwer, F., Wegley-Kelly, L., Quistad, S.D., Carlson, C.A., Leichter, J.J., Hatay, M., Smith, J.E., 2013. Influence of coral and algal exudates on microbially mediated reef metabolism. Peer] 1:e:108. https://doi.org/10.7717/peerj.108.

Halim, M., Spaccini, R., Parlanti, E., Amezghal, A., Piccolo, A., 2013. Differences in fluorescence properties between humic acid and its size fractions separated by preparative HPSEC. J. Geochem. Explor. 129:23-27. https://doi.org/10.1016/j.gexplo.2012.11.006.

He, W., Chen, M., Schlautman, M.A., Hur, J., 2016. Dynamic exchanges between DOM and POM pools in coastal and inland aquatic ecosystems: a review. Sci. Total Environ. 551-552:415-428. https://doi.org/10.1016/j.scitotenv.2016.02.031.

Hédouin, L., Pringault, O., Bustamante, P., Fichez, R., Warnau, M., 2011. Validation of two tropical marine bivalves as bioindicators of mining contamination in the New
Caledonia lagoon: field transplantation experiments. Water Res. 45:483-496. https://doi.org/10.1016/j.watres.2010.09.002.

Helms, J.R., Stubbins, A., Ritchie, J.D., Minor, E.C., Kieber, D.J., Mopper, K., 2008. Absorption spectral slopes and slope ratios as indicators of molecular weight, source, and photobleaching of chromophoric dissolved organic matter. Limnol. Oceanogr. 53, 955-969.

Henderson, R.K., Baker, A., Parsons, S.A., Jefferson, B., 2008. Characterisation of algogenic organic matter extracted from cyanobacteria, green algae and diatoms. Water Res. 42:3435-3445. https://doi.org/10.1016/j.watres.2007.10.032.

Hénin, C., Guillerm, J.-M., Chabert, L., 1984. Circulation autour superficielle de la NouvelleCalédonie. Oceanogr. Trop. 19, 113-126.

Hernes, P.J., Bergamaschi, B.A., Eckard, R.S., Spencer, R.G.M., 2009. Fluorescence-based proxies for lignin in freshwater dissolved organic matter. J. Geophys. Res. Biogeosci. 114:1-10. https://doi.org/10.1029/2009JG000938.

Huguet, A., Vacher, L., Relexans, S., Saubusse, S., Froidefond, J.M., Parlanti, E., 2009. Properties of fluorescent dissolved organic matter in the Gironde estuary. Org. Geochem. 40:706-719. https://doi.org/10.1016/j.orggeochem.2009.03.002.

Jaffé, R., Cawley, K.M., Yamashita, Y., 2014. Applications of excitation emission matrix fluorescence with parallel factor analysis (EEM-PARAFAC) in assessing environmental dynamics of natural dissolved organic matter (DOM) in aquatic environments: a review. ACS Symp. Ser. 1160:27-73. https://doi.org/10.1021/bk-2014-1160.ch003.

Jollit, I., Leopold, M., Guillemot, N., David, G., Chabanet, P., Lebigre, J.M., Ferraris, J., 2010. Geographical aspects of informal reef fishery systems in New Caledonia. Mar. Pollut. Bull. 61:585-597. https://doi.org/10.1016/j.marpolbul.2010.06.033.

Jørgensen, L., Stedmon, C.A., Kragh, T., Markager, S., Middelboe, M., Søndergaard, M., 2011. Global trends in the fluorescence characteristics and distribution of marine dissolved organic matter. Mar. Chem. 126:139-148. https://doi.org/10.1016/j.marchem.2011.05.002. Komada, T., Schofield, O.M.E., Reimers, C.E., 2002. Fluorescence characteristics of organic matter released from coastal sediments during resuspension. Mar. Chem. 79:81-97. https://doi.org/10.1016/S0304-4203(02)00056-7.

Kowalczuk, P., Zabłocka, M., Sagan, S., Kuliński, K., 2010. Fluorescence measured in situ as a proxy of CDOM absorption and DOC concentration in the Baltic Sea. Oceanologia 52:431-471. https://doi.org/10.5697/oc.52-3.431.

Kowalczuk, P., Tilstone, G.H., Zab, M., Röttgers, R., Thomas, R., 2013. Composition of dissolved organic matter along an Atlantic Meridional Transect from fluorescence spectroscopy and Parallel Factor Analysis. Mar. Chem. 157:170-184. https://doi.org/ 10.1016/j.marchem.2013.10.004.

Labrosse, P., Fichez, R., Farman, R., Adams, T., 2000. Seas at the millennium: an environmental evaluation. In: Sheppard, C.R.C. (Ed.), 2. Regional Chapters: The Indian Ocean to the Pacific. E-Publishing Inc., New Caledonia, pp. 723-736.

Lebaron, P., Servais, P., Agogué, H., Courties, C., Joux, F., 2001. Does the high nucleic acid content of individual bacterial cells allow us to discriminate between active cells and inactive cells in aquatic systems. Appl. Environ. Microbiol. 67:1775-1782. https://doi.org/10.1128/AEM.67.4.1775-1782.2001.

Lu, C., Benner, R., Fichot, C.G., Fukuda, H., Yamashita, Y., Ogawa, H., 2016. Sources and transformations of dissolved lignin phenols and chromophoric dissolved organic matter in Otsuchi Bay, Japan. Front. Mar. Sci. 3:1-12. https://doi.org/10.3389/ fmars.2016.00085

Luciani, X., Mounier, S., Paraquetti, H.H.M., Redon, R., Lucas, Y., Bois, A., Lacerda, L.D., Raynaud, M., Ripert, M., 2008. Tracing of dissolved organic matter from the Sepetiba Bay (Brazil) by PARAFAC analysis of total luminescence matrices. Mar. Environ. Res. 65:148-157. https://doi.org/10.1016/j.marenvres.2007.09.004

Maki, T., Ishikawa, A., Mastunaga, T., Pointing, S.B., Saito, Y., Kasai, T., Watanabe, K., Aoki, K., Horiuchi, A., Lee, K.C., Hasegawa, H., Iwasaka, Y., 2016. Atmospheric aerosol deposition influences marine microbial communities in oligotrophic surface waters of the western Pacific Ocean. Deep-Sea Res. I Oceanogr. Res. Pap. 118:37-45. https:// doi.org/10.1016/j.dsr.2016.10.002.

Marchand, C., Allenbach, M., Lallier-Vergès, E., 2011. Geoderma relationships between heavy metals distribution and organic matter cycling in mangrove sediments (Conception Bay, New Caledonia). Geoderma 160:444-456. https://doi.org/10.1016/ j.geoderma.2010.10.015.

Marchesiello, P., Lefèvre, J., Vega, A., Couvelard, X., Menkes, C., 2010. Coastal upwelling, circulation and heat balance around New Caledonia's barrier reef. Mar. Pollut. Bull. 61:432-448. https://doi.org/10.1016/j.marpolbul.2010.06.043.

Mari, X., Rochelle-Newall, E., Torréton, J.-P., Pringault, O., Jouon, A., Migon, C., 2007. Water residence time: a regulatory factor of the DOM to POM transfer efficiency. Limnol. Oceanogr. 52:808-819. https://doi.org/10.4319/lo.2007.52.2.0808.

Massicotte, P., Frenette, J.J., 2011. Spatial connectivity in a large river system: resolving the sources and fate of dissolved organic matter. Ecol. Appl. 21:2600-2617. https:// doi.org/10.1890/10-1475.1.

Mayer, L.M., Schick, L.L., Loder, T.C., 1999. Dissolved protein fluorescence in two maine estuaries. Mar. Chem. 64:171-179. https://doi.org/10.1016/S0304-4203(98)00072-3.

Mendoza, W.G., Kang, Y., Zika, R.G., 2012. Resolving DOM fluorescence fractions during a Karenia brevis bloom patch on the Southwest Florida shelf. Cont. Shelf Res. 32: 121-129. https://doi.org/10.1016/j.csr.2011.11.001.

Mignone, R.A., Martin, M.V., Morán Vieyra, F.E., Palazzi, V.I., Lõpez De Mishima, B., Mártire, D.O., Borsarelli, C.D., 2012. Modulation of optical properties of dissolved humic substances by their molecular complexity. Photochem. Photobiol. 88:792-800. https:// doi.org/10.1111/j.1751-1097.2012.01135.x.

Mopper, K., Kieber, D.J., Stubbins, A., 2015. Marine photochemistry of organic matter: processes and impacts. In: Hansell, D.A., Carlson, C.A. (Eds.), Biogeochemistry of Marine Dissolved Organic Matter, 2nd Edition Academic Press, pp. 390-431.

Mora, S., Demers, S., Vernet, M., 2000. The Effects of UV Radiation in the Marine Environment. 1st edition. Cambridge University Press, pp. 39-355.

Moreton, B.M., 2009. Development of a field preconcentration/elution unit for routine determination of dissolved metal concentrations by ICP-OES in marine waters: 
application for monitoring of the New Caledonia lagoon. Geostand. Geoanal. Res. 33 205-218.

Mounier, S., Zhao, H., Garnier, C., Redon, R., 2011. Copper complexing properties of dissolved organic matter: PARAFAC treatment of fluorescence quenching. Biogeochemistry 106:107-116. https://doi.org/10.1007/s10533-010-9486-6.

Murphy, J., Riley, J.P., 1962. A modified single solution method for the determination of phosphate in natural waters. Anal. Chim. Acta 27, 31-36.

Murphy, K.R., Stedmon, C.a., Waite, T.D., Ruiz, G.M., 2008. Distinguishing between terrestrial and autochthonous organic matter sources in marine environments using fluorescence spectroscopy. Mar. Chem. 108:40-58. https://doi.org/10.1016/ j.marchem.2007.10.003.

Murphy, K.R., Stedmon, C.A., Graeber, D., Bro, R., 2013. Fluorescence spectroscopy and multiway techniques. PARAFAC. Anal. Methods 5:6557. https://doi.org/10.1039/c3ay41160e.

Nelson, N.B., Siegel, D.A., 2013. The global distribution and dynamics of chromophoric dissolved organic matter. Annu. Rev. Mar. Sci. Vol. 5 (5):447-476. https://doi.org/ 10.1146/annurev-marine-120710-100751.

Nelson, N.B., Siegel, D.A., Carlson, C.A., Swan, C., Smethie, W.M., Khatiwala, S., 2007. Hydrography of Chromophoric Dissolved Organic Matter in the North Atlantic. 54: pp. 710-731. https://doi.org/10.1016/j.dsr.2007.02.006.

Nelson, C.E., Goldberg, S.J., Wegley Kelly, L., Haas, A.F., Smith, J.E., Rohwer, F., Carlson, C.A., 2013. Coral and macroalgal exudates vary in neutral sugar composition and differentially enrich reef bacterioplankton lineages. ISME J. 7:962-979. https://doi.org/ 10.1038/ismej.2012.161.

Nelson, C.E., Donahue, M.J., Dulaiova, H., Goldberg, S.J., La Valle, F.F., Lubarsky, K., Miyano, J., Richardson, C., Silbiger, N.J., Thomas, F.I.M., 2015. Fluorescent dissolved organic matter as a multivariate biogeochemical tracer of submarine groundwater discharge in coral reef ecosystems. Mar. Chem. 177:232-243. https://doi.org/10.1016/ j.marchem.2015.06.026.

Nieto-Cid, M., Álvarez-Salgado, X.a., Gago, J., Pérez, F.F., 2005. DOM fluorescence, a tracer for biogeochemical processes in a coastal upwelling system (NW Iberian peninsula). Mar. Ecol. Prog. Ser. 297:33-50. https://doi.org/10.3354/meps297033.

Nimptsch, J., Woelfl, S., Osorio, S., Valenzuela, J., Ebersbach, P., von Tuempling, W., Palma, R., Encina, F., Figueroa, D., Kamjunke, N., Graeber, D., 2015. Tracing dissolved organic matter (DOM) from land-based aquaculture systems in North Patagonian streams. Sci. Total Environ. 537:129-138. https://doi.org/10.1016/j.scitotenv.2015.07.160.

Organelli, E., Bricaud, A., Antoine, D., Matsuoka, A., 2014. Seasonal dynamics of light absorption by chromophoric dissolved organic matter (CDOM) in the NW Mediterranean Sea (BOUSSOLE site). Deep. Res. Part I Oceanogr. Res. Pap. 91:72-85. https:// doi.org/10.1016/j.dsr.2014.05.003

Pandey, A.K., Pandey, S.D., Misra, V., 2000. Stability constants of metal-humic acid complexes and its role in environmental detoxification. Ecotoxicol. Environ. Saf. 47: 195-200. https://doi.org/10.1006/eesa.2000.1947.

Pandi, S.R., Kiran, R., Sarma, N.S., Srikanth, A.S., Sarma, V.V.S.S., Krishna, M.S. Bandyopadhyay, D., Prasad, V.R., Acharyya, T., Reddy, K.G., 2014. Contrasting phytoplankton community structure and associated light absorption characteristics of the western Bay of Bengal. Ocean Dyn. 64:89-101. https://doi.org/10.1007/s10236-0130678-1.

Payri, C., Benzoni, F., Houlbreque, F., 2017. Le blanchissement des coraux: l'épisode de 2016 en Nouvelle Calédonie. l'ENA hors les murs. pp. 13-16.

Pitta, E., Zeri, C., Tzortziou, M., Mousdis, G., Scoullos, M., 2016. Seasonal variations in dissolved organic matter composition using absorbance and fluorescence spectroscopy in the Dardanelles Straits - North Aegean Sea mixing zone. Cont. Shelf Res. https:// doi.org/10.1016/j.csr.2016.07.013.

Plaza, C., Brunetti, G., Senesi, N., Polo, A., 2006. Molecular and quantitative analysis of metal ion binding to humic acids from sewage sludge and sludge-amended soils by fluorescence spectroscopy. Environ. Sci. Technol. 40:917-923. https://doi.org/ $10.1021 / \mathrm{es} 051687 \mathrm{w}$.

Raimbault, P., Slawk, G., Coste, B., Fry, J., 1990. Feasability of using an automated procedure for the determination of seawater nitrate in the $0-100 \mathrm{nM}$ range: examples from field and cultures. Mar. Biol. 104, 347-351.

Raimbault, P., Diaz, F., Pouvesle, W., Boudjellal, B., 1999. Simultaneous determination of particulate organic carbon, nitrogen and phosphorus collected on filters, using a semi-automatic wet-oxidation method. Mar. Ecol. Prog. Ser. 180:289-295. https:// doi.org/10.3354/meps180289.

Rochelle-Newall, E., Hulot, F.D., Janeau, J.L., Merroune, A., 2014. CDOM fluorescence as a proxy of DOC concentration in natural waters: a comparison of four contrasting tropical systems. Environ. Monit. Assess. 186:589-596. https://doi.org/10.1007/s10661013-3401-2.

Romera-Castillo, C., Sarmento, H., Álvarez-Salgado, X.A., Gasol, J.M., Marrasé, C., 2010. Production of chromophoric dissolved organic matter by marine phytoplankton. Limnol. Oceanogr. 55:446-454. https://doi.org/10.4319/lo.2010.55.1.0446.

Ryan, D.K., Thompson, C.P., Weber, J.H., 1983. Comparison of Mn2 +, Co2 +, and Cu2 + binding to fulvic acid as measured by fluorescence quenching. Can. J. Chem. 61, 1505-1509.

Santinelli, C., 2016. Dissolved organic matter dynamics in surface waters affected by oil spill pollution: results from the serious game exercise. Deep-Sea Res. II Top. Stud. Oceanogr. 133:1-12. https://doi.org/10.1016/j.dsr2.2016.05.027.

Saraceno, J.F., Pellerin, B.A., Downing, B.D., Boss, E., Bachand, P.A.M., Bergamaschi, B.A., 2009. High-frequency in situ optical measurements during a storm event: assessing relationships between dissolved organic matter, sediment concentrations, and hydrologic processes. J. Geophys. Res. Biogeosci. 114:1-11. https://doi.org/10.1029/ 2009JG000989.

Schlitzer, R., 2014. Ocean Data View, odv.awi.de.

Sempéré, R., Para, J., Tedetti, M., Charrière, B., Mallet, M., 2015. Variability of solar radiation and CDOM in surface coastal waters of the northwestern Mediterranean Sea. Photochem. Photobiol. 91:851-861. https://doi.org/10.1111/php.12434.
Shiller, A.M., 1997. Manganese in surface waters of the Atlantic Ocean. Geophys. Res. Lett. 24:1495-1498. https://doi.org/10.1029/97GL01456.

Siegel, D.A., Maritorena, S., Nelson, N.B., Hansell, D.A., Lorenzi-Kayser, M., 2002. Global distribution and dynamics of colored dissolved and detrital organic materials. J. Geophys. Res. 107:1-14. https://doi.org/10.1029/2001JC000965.

Stedmon, C.a., Markager, S., 2005. Resolving the variability of dissolved organic matter fluorescence in a temperate estuary and its catchment using PARAFAC analysis. Limnol. Oceanogr. 50:686-697. https://doi.org/10.4319/lo.2005.50.2.0686.

Stedmon, C.A., Markager, S., Tranvik, L., Kronberg, L., Slätis, T., Martinsen, W., 2007. Photochemical production of ammonium and transformation of dissolved organic matter in the Baltic Sea. Mar. Chem. 104:227-240. https://doi.org/10.1016/ j.marchem.2006.11.005.

Steinberg, D.K., Nelson, N.B., Carlson, C.A., Prusak, A.C., 2004. Production of chromophoric dissolved organic matter (CDOM) in the open ocean by zooplankton and the colonial cyanobacterium Trichodesmium spp. Mar. Ecol. Prog. Ser. 267:45-56. https://doi.org/ 10.3354/meps267045.

Stijn, B., Fien, D., Verheyen, L., Roel, M., Eric, S., 2011. Metal complexation properties of freshwater dissolved organic matter are explained by its aromaticity and by anthropogenic ligands. Environ. Sci. Technol. 45, 1-21.

Su, R., Bai, Y., Zhang, C., Shi, X., 2015. The assessment of the spatial and seasonal variability of chromophoric dissolved organic matter in the southern Yellow Sea and the East China Sea. Mar. Pollut. Bull. 100:523-533. https://doi.org/10.1016/ j.marpolbul.2015.09.002.

Tedetti, M., Cuet, P., Guigue, C., Goutx, M., 2011. Characterization of dissolved organic matter in a coral reef ecosystem subjected to anthropogenic pressures (La Réunion Island, Indian Ocean) using multi-dimensional fluorescence spectroscopy. Sci. Total Environ. 409:2198-2210. https://doi.org/10.1016/j.scitotenv.2011.01.058.

Tedetti, M., Longhitano, R., Garcia, N., Guigue, C., Ferretto, N., Goutx, M., 2012. Fluorescence properties of dissolved organic matter in coastal Mediterranean waters influenced by a municipal sewage effluent (Bay of Marseilles, France). Environ. Chem. 9: 438-449. https://doi.org/10.1071/EN12081.

Tedetti, M., Marie, L., Röttgers, R., Rodier, M., Van Wambeke, F., Helias, S., Caffin, M., Cornet-Barthaux, V., Dupouy, C., 2016. Evolution of dissolved and particulate chromophoric materials during the VAHINE mesocosm experiment in the New Caledonian coral lagoon (south-west Pacific). Biogeosciences 13:3283-3303. https://doi.org/ 10.5194/bg-13-3283-2016

Tenorio, M.M., Borgne, R., Le Rodier, M., Neveux, J., 2005. The impact of terrigeneous inputs on the Bay of Ouinne (New Caledonia) phytoplankton communities: a spectrofluorometric and microscopic approach. Estuar. Coast. Shelf Sci. 64:531-545. https:// doi.org/10.1016/j.ecss.2005.02.030.

Troupin, C., Barth, A., Sirjacobs, D., Ouberdous, M., Brankart, J.M., Brasseur, P., Rixen, M. Alvera-Azcárate, A., Belounis, M., Capet, A., Lenartz, F., Toussaint, M.E., Beckers, J.M. 2012. Generation of analysis and consistent error fields using the Data Interpolating Variational Analysis (DIVA). Ocean Model 52-53:90-101. https://doi.org/10.1016/ j.ocemod.2012.05.002.

Vantrepotte, V., Danhiez, F.-P., Loisel, H., Ouillon, S., Mériaux, X., Cauvin, A., Dessailly, D. 2015. CDOM-DOC relationship in contrasted coastal waters: implication for DOC retrieval from ocean color remote sensing observation. Opt. Express 23:33. https:// doi.org/10.1364/OE.23.000033.

Ventry, L.S., Ryan, D.K., Gilbert, T.R., 1991. A rapid fluorescence quenching method for the determination of equilibrium parameters for copper(II) complexation by humic materials. Microchem. J. 44:201-214. https://doi.org/10.1016/0026-265X(91)90099-B.

Wang, Z., Cao, J., Meng, F., 2015. Interactions between protein-like and humic-like components in dissolved organic matter revealed by fluorescence quenching. Water Res. 68: 404-413. https://doi.org/10.1016/j.watres.2014.10.024.

Weishaar, J.L., Aiken, G.R., Bergamaschi, B.A., Fram, M.S., Fujii, R., Mopper, K., 2003. Evaluation of specific ultraviolet absorbance as an indicator of the chemical composition and reactivity of dissolved organic carbon. Environ. Sci. Technol. 37:4702-4708. https://doi.org/10.1021/es030360x.

Wolanski, E., Andutta, F., Deleersnijder, E., Li, Y., Thomas, C.J., 2017. The Gulf of Carpentaria heated Torres Strait and the Northern Great Barrier Reef during the 2016 mass coral bleaching event. Estuar. Coast. Shelf Sci. 194:172-181. https:// doi.org/10.1016/j.ecss.2017.06.018.

Wu, J., Zhang. H., He, P., Shao, L., 2010. Insight into the heavy metal binding potential of dissolved organic matter in MSW leachate using EEM quenching combined with PARAFAC analysis. Water Res. 45:1711-1719. https://doi.org/10.1016/j.watres.2010.11.022.

Xu, H., Guo, L., 2017. Molecular size-dependent abundance and composition of dissolved organic matter in river, lake and sea waters. Water Res. 117:115-126. https://doi.org/ 10.1016/j.watres.2017.04.006.

Yamashita, Y., Tanoue, E., 2004. Chemical characteristics of amino acid-containing dissolved organic matter in seawater. Org. Geochem. 35:679-692. https://doi.org/ 10.1016/j.orggeochem.2004.02.007.

Yamashita, Y., Maie, N., Briceno, H., Jaffe, R., 2010a. Optical characterization of dissolved organic matter in tropical rivers of the Guayana Shield, Venezuela. J. Geophys. Res. Biogeosci. 115. https://doi.org/10.1029/2009JG000987.

Yamashita, Y., Cory, R.M., Nishioka, J., Kuma, K., Tanoue, E., Jaffé, R., 2010b. Fluorescence characteristics of dissolved organic matter in the deep waters of the Okhotsk Sea and the northwestern North Pacific Ocean. Deep-Sea Res. II Top. Stud. Oceanogr. 57:1478-1485. https://doi.org/10.1016/j.dsr2.2010.02.016.

Yamashita, Y., Fichot, C.G., Shen, Y., Jaffé, R., Benner, R., 2015. Linkages among fluorescent dissolved organic matter, dissolved amino acids and lignin-derived phenols in a river-influenced ocean margin. Front. Mar. Sci. 2:1-14. https://doi.org/10.3389/ fmars.2015.00092

Zhang, Y., Liu, X., Wang, M., Qin, B., 2013. Organic geochemistry compositional differences of chromophoric dissolved organic matter derived from phytoplankton and macrophytes. Org. Geochem. 55:26-37. https://doi.org/10.1016/j.orggeochem.2012.11.007. 